\title{
MASTER
}

OAK

RIDGE

NATIONAL

LABORATORY

UNION

CARBIDE

\section{Characterization of Three Fibrous Insulations for Potential HTGR Application}

\author{
J. E. Selle
}

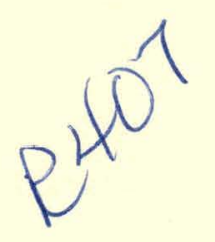

OPERATED BY

UNION CARBIDE CORPORATION FOR THE UNITED STATES DEPARTMENT OF ENERGY

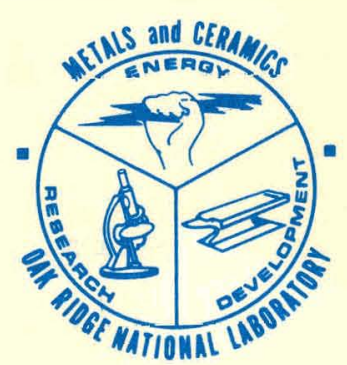




\section{DISCLAIMER}

This report was prepared as an account of work sponsored by an agency of the United States Government. Neither the United States Government nor any agency Thereof, nor any of their employees, makes any warranty, express or implied, or assumes any legal liability or responsibility for the accuracy, completeness, or usefulness of any information, apparatus, product, or process disclosed, or represents that its use would not infringe privately owned rights. Reference herein to any specific commercial product, process, or service by trade name, trademark, manufacturer, or otherwise does not necessarily constitute or imply its endorsement, recommendation, or favoring by the United States Government or any agency thereof. The views and opinions of authors expressed herein do not necessarily state or reflect those of the United States Government or any agency thereof. 


\section{DISCLAIMER}

Portions of this document may be illegible in electronic image products. Images are produced from the best available original document. 
Printed in the United States of America. Available from National Technical Information Service

U.S. Department of Commerce

5285 Port Royal Road, Springfield, Virginia 22161

NTIS price codes-Printed Copy: A03; Microfiche A01

This report was prepared as an account of work sponsored by an agency of the United States Government. Neither the United States Government nor any agency thereof, nor any of their employees, makes any warranty, express or implied, or assumes any legal liability or responsibility for the accuracy, completeness, or usefulness of any information, apparatus, product, or process disclosed, or represents that its use would not infringe privately owned rights. Reference herein to any specific commercial product, process, or service by trade name, trademark, manufacturer, or otherwise, does not necessarily constitute or imply its endnrsement, recommendation, or favoring by the United States Government or any agency thereof. The views and opinions of authors expressed heieiı du iuul necessarily state or reflect those of the United States Government or any agency thereof. 
ORNL/TM-7507

Distribution

Category UC-77

Contract No. W-7405-eng-26

METALS AND CERAMICS DIVISION

HTGR BASE TECHNOLOGY PROGRAM

Structural Materials Program (FTP/A 01332, AG 250500 0)

\title{
CHARACTERIZATION OF THREE FIBROUS INSULATIONS FOR POTENTIAL HTGR APPLICATION
}

\author{
J. E. Selle
}

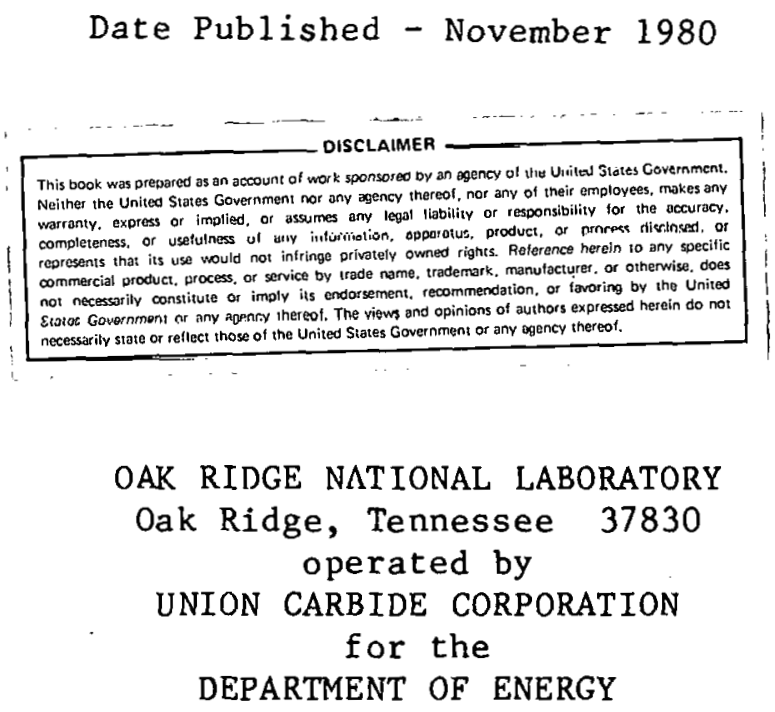




\section{THIS PAGE WAS INTENTIONALLY LEFT BLANK}




\section{CONTENTS}

ABSTRACT. ........................................

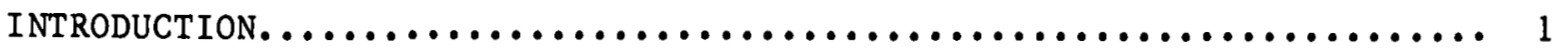

PROCEDURE........................................... 2

Ignition Studies and Bulk Density Measurements............... 2

Res1lience Tests................................... 3

Helium Permeation.................................. 3

Compressive Stress-strain........................... 3

RESULTS......................................... 4

Spectrographic Analysis............................. 4

X-Ray Diffractometry............................... 4

Scanning Electron Microscopy........................ 6

Ignition Tests and Density Measurements.................. 7

Resilience Tests.................................. 8

Helium Permeation.................................. 9

Compressive Stress-Strain.......................... 10

ConCLUSIONS....................................... 11

ACKNOWLEDGMENTS. .................................... 12

REFERENCES ....................................... 13

APPENDIX A......................................... 17 
CHARACTERIZATION OF THREE FIBROUS INSULATIONS FOR

POTENTIAL HTGR APPLICATION

J. E. Sel1e*

ABSTRACT

Three fibrous insulation materials manufactured by Babcock and Wilcox were characterized for possible use as HTGR core thermal insulations. These materials (Unifelt 3000 board, Unifelt 2600 board, and Kaowool blanket) were characterlzed by spectrographic analysis, $x$-ray diffractometry, scanning electron microscopy, ignition studies and bulk density measurements, resilience tests, hellum permeation tests, and compressive stress-strain tests. Of these properties, resilience is the most important for determining acceptability of material for HTGR use. The arbitrary resilience acceptability criterion is $90 \%$ or greater after $20 \mathrm{~h}$ at $816^{\circ} \mathrm{C}\left(1500^{\circ} \mathrm{F}\right)$. Based on the resi1 lence test, the Unifelt 3000 was acceptable, the Unifelt 2600 was marginal, and the Kaowool was unacceptable.

\section{INTRODUCTION}

As part of the HTGR Structural Ceramics Program, work was initiated on the characterization of fibrous insulations for potential use as reactor core thermal insulations. To avold duplication of work at General Atomic Company, discussions were held and it was agreed that we would investigate three fibrous insulations manufactured by Babcock and Wilcox (B\&W): Unifelt 3000 board, Unifelt 2600 board, and Kaowool blanket. General Atomic has investigated insulation materials produced by other vendors. 1,2

Unifelt 3000 board is formed from a slurry of SAFFIL (trademark of Imperial Chemical Industries, Ltd.) alumina fiber, Kaowool aluminum silicate fiber, and an organic binder. Its maximum use limit is $1650^{\circ} \mathrm{C}$ $\left(3000^{\circ} \mathrm{F}\right)$. Unifelt 2600 is simflar but has a higher percentage of the Kaowool aluminum silicate fiber and a maximum use limit of $1425^{\circ} \mathrm{C}$

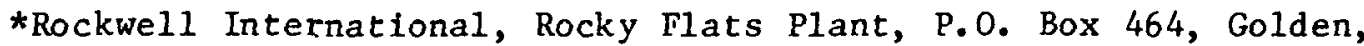
Colorado 80401 .
} 
$\left(2600^{\circ} \mathrm{F}\right)$. Both Unifelt 3000 and Unifelt 2600 contain an organic binder that must be baked out prior to use as described later. The as-recelved Unifelt boards are stiff, easy to handle, and easy to cut to size. However, after ignition of the organic binder, handling is more difficult because the material tends to delaminate across the thickness of the board. It also becomes light, with lower tensile strength, and care must be exercised in handling. Kaowool, a needled blanket of aluminum silficate fibers has good handling characteristics, no organic binder, and needs no baking prior to use.

PROCEDURE

To assess their potential for HTGR application, these materlals were characterized by:

1. spectrographic analysis,

2. x-ray diffractometry,

3. scanning electron microscopy (SEM),

4. ignition studies and bulk density measurements,

5. resilience tests,

6. helium permeation tests, and

7. compressive stress-strain tests.

Procedures for spectrographic analysis, $x$-ray diffractrometry, and SEM are reasonably standard and need not be repeated here. However, to establish a reference for comparison with other materials, the procedures for the remaining tests are described.

Ignition Studies and Bulk Density Measurements

Kectangular blocks $[76 \mathrm{~mm}$ ( 3 in.) long $\times 63-76 \mathrm{~cm}(2.5-3 \mathrm{in.})$ wide $x$ nominal thickness $\sim 63 \mathrm{~mm}(2.5 \mathrm{in.})$ ] were used for all except the helium permeation tests. Dimensions were measured to the nearest $0.1 \mathrm{~mm}$ with a vernier caliper, and the weight of each sample was measured to the nearest $0.01 \mathrm{~g}$.

The blocks were placed in a preheated pot-type furnace with an air atmosphere and held for a predetermined time at 400 or $500^{\circ} \mathrm{C}(752$ or 
$\left.932^{\circ} \mathrm{F}\right)$. After blocks were removed from the furnace, the dimensions and weight were again recorded.

\section{Resilience Tests}

Specimens for these tests were $76 \mathrm{~mm}$ ( 3 in.) long $\times 63 \mathrm{~mm}$ (2.5 in.) wide $\times$ nominal thickness. The thickness was measured to the nearest $0.1 \mathrm{~mm}$ while under a stress of $167 \mathrm{~Pa}\left(3.51 \mathrm{~b} / \mathrm{ft}^{2}\right)$, which was obtained by placing a $76 \times 63 \times 6.35 \mathrm{~mm}(3 \times 2.5 \times 0.25$ in. $)$ aluminum plate on top of the specimen. The specimens (without the aluminum plate) were then placed in stainless steel holders and compressed to $75 \%$ of the thickness as measured above, heated for $20 \mathrm{~h}$ at $816^{\circ} \mathrm{C}\left(1500^{\circ} \mathrm{F}\right)$ in helium, and cooled in helium. After the specimens were released from the holders, the thickness was again measured to the nearest $0.1 \mathrm{~mm}$ while under the $167-\mathrm{Pa}$ stress. Eight specimens of each material were tested at $816^{\circ} \mathrm{C}\left(1500^{\circ} \mathrm{F}\right)$, and two specimens of Unifelt 3000 and two of Unifelt 2600 were tested at $982^{\circ} \mathrm{C}$ $\left(1800^{\circ} \mathrm{F}\right)$.

\section{Helium Permeation}

The apparatus for measuring the helium permeation rate is shown in Fig. 1. The doughnut-shaped specimen is $165 \mathrm{~mm}$ (6.5 in.) in diameter with a $51 \mathrm{~mm}$ (2-in.) hole in the center. The specimen holder is adjustable so that any desired compressed density can be obtained. Helium flowed into the center hole and escaped radially through the side of the specimen. The helium flow rate was measured as a function of pressure difference at each compressed density.

\section{Compressive Stress-Strain}

Specimens measuring approximately $76 \times 76 \mathrm{~mm}(3 \times 3$ in.) or $63.5 \times$ $76 \mathrm{~mm}(2.5 \times 3 \mathrm{in.})$ were placed in an Instron machine and loaded in compression. A $0.2-1$ b load was applied, the crosshead was adjusted to zero, and the thickness of the specimen was measured. The predetermined load was applied and held for $300 \mathrm{~s}$, and the crosshead movement and the 
final thickness were measured. Tests were run sequentially from lower load to higher load on the same specimen. Between tests the load was

ORNL.DWG 80-12125

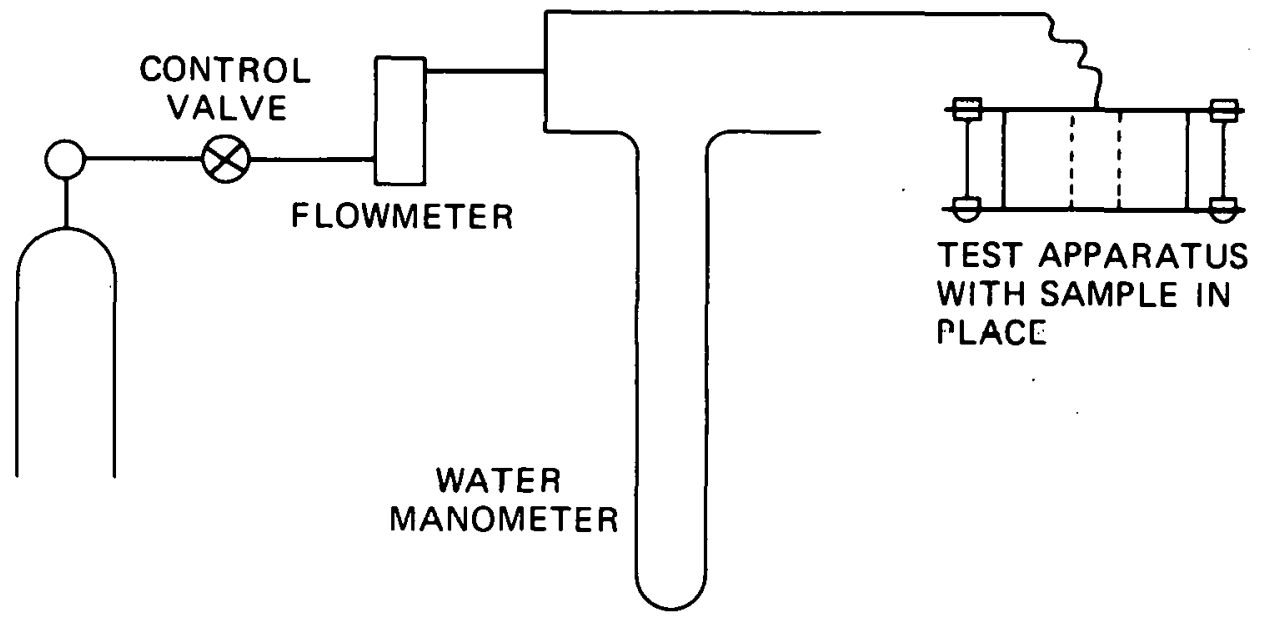

Fig. 1. Schematic of Helium Permeation Test Apparatus.

removed for $300 \mathrm{~s}$ to allow the specimen to recover from the prior deformation before applying the new load.

\section{RESULTS}

Spectrographic Analysis

Results from the spectrographic analyses are given in Table 1 . silicon, aluminum, and oxygen are the primary constitutents and are not included in these analyses. Nominal compositions for each material are given in Table 2.

\section{X-Ray Diffractometry}

$x$-ray diffractometry results and d-spacings for the various peaks are given in Appendix A. Unifelt 3000 contained a small amount of glassy phase, and crystalline phases included $\alpha-\mathrm{Al}_{2} \mathrm{O}_{3}$ (corundum), $\delta-\mathrm{Al}_{2} \mathrm{O}_{3}, \mathrm{Al}_{2} \mathrm{SiO}_{5}$, $\mathrm{Na}_{6} \mathrm{Al}_{4} \mathrm{Si}_{4} \mathrm{O}_{17}$, and $\mathrm{MoSi}_{2}$. A few other peaks from undetermined phases were 
Table 1. Spectrographic Analysis of Impurities in Fibrous Insulations

\begin{tabular}{|c|c|c|c|}
\hline Impur1ty & $\begin{array}{l}\text { Un1felt } 3000 \\
\quad(\mathrm{ppm})\end{array}$ & $\begin{array}{l}\text { Untfelt } 2600 \\
(\mathrm{ppm})\end{array}$ & $\begin{array}{c}\text { Kaowool } \\
(\mathrm{ppm})\end{array}$ \\
\hline $\mathrm{Ag}$ & $<0.005$ & $<0.005$ & $<0.005$ \\
\hline B & $<0.01$ & $<0.01$ & $<0.01$ \\
\hline $\mathrm{Ba}$ & 0.05 & 0.1 & 0.08 \\
\hline $\mathrm{Be}$ & $<0.005$ & $<0.005$ & $<0.005$ \\
\hline B1 & $<0.02$ & $<0.02$ & $<0.02$ \\
\hline $\mathrm{Ca}$ & 0.07 & 0.1 & 0.09 \\
\hline $\mathrm{Cd}$ & $<0.05$ & $<0.05$ & $<0.05$ \\
\hline Co & $<0.02$ & $<0.02$ & $<0.02$ \\
\hline $\mathrm{Cr}$ & 0.05 & 0.1 & 0.02 \\
\hline Cs & $<0.1$ & $<0.1$ & $<0.1$ \\
\hline $\mathrm{Cu}$ & $<0.01$ & 0.1 & $<0.01$ \\
\hline $\mathrm{Fe}$ & 0.3 & 0.7 & 0.5 \\
\hline $\mathrm{Hg}$ & $<0.05$ & $<0.05$ & $<0.05$ \\
\hline In & $<0.05$ & $<0.05$ & $<0.05$ \\
\hline $\mathrm{K}$ & $<0.02$ & 0.5 & $<0.02$ \\
\hline $\mathrm{L}_{1}$ & 0.005 & 0.01 & 0.007 \\
\hline $\mathrm{Mg}$ & 0.17 & 0.2 & 0.15 \\
\hline Mn & 0.01 & 0.01 & 0.01 \\
\hline Mo & $<0.01$ & $<0.01$ & $<0.01$ \\
\hline $\mathrm{Na}$ & 0.05 & 0.3 & 0.1 \\
\hline $\mathrm{Nb}$ & $<0.05$ & $<0.05$ & $<0.05$ \\
\hline $\mathrm{N} 1$ & $<0.02$ & 0.02 & $<0.02$ \\
\hline $\mathrm{Pb}$ & $<0.02$ & $<0.02$ & $<0.02$ \\
\hline $\mathrm{Rb}$ & $<0.02$ & $<0.02$ & $<0.02$ \\
\hline $\mathrm{Sn}$ & $<0.02$ & $<0.02$ & $<0.02$ \\
\hline $\mathrm{Sr}$ & $<0.02$ & 0.05 & 0.05 \\
\hline $\mathrm{Ta}$ & $<0.05$ & $<0.05$ & $<0.05$ \\
\hline $\mathrm{Ti}$ & 0.6 & 1 & 1 \\
\hline $\mathrm{v}$ & 0.02 & 0.02 & 0.02 \\
\hline W & $<0.05$ & $<0.05$ & $<0.05$ \\
\hline $\mathrm{Zn}$ & $<0.05$ & $<0.05$ & $<0.05$ \\
\hline $2 r$ & 0.02 & 0.02 & 0.02 \\
\hline
\end{tabular}


Table 2. Nominal Compositions $a$ (\%) of

Fibrous Insulations

\begin{tabular}{lccc}
\hline & $\begin{array}{c}\text { Unifelt } \\
\text { Board }\end{array}$ & $\begin{array}{c}\text { Unifelt 2600 } \\
\text { Board }\end{array}$ & Kaowool \\
\hline $\mathrm{Al}_{2} \mathrm{O}_{3}$ & 71.7 & 55.7 & 45 \\
$\mathrm{SiO}_{2}$ & 22.8 & 38.7 & 52 \\
Inorganics & 0.3 & 0.5 & $\sim 3.3^{b}$ \\
$\begin{array}{l}\text { We1ght loss on } \\
\text { ignitinn }\end{array}$ & 5.5 & 5.5 & \\
\hline
\end{tabular}

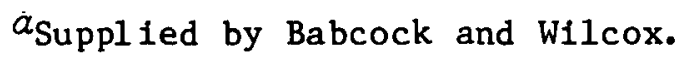

$b_{1.3 \%} \mathrm{Fe}_{2} \mathrm{O}_{3}, 1.7 \% \mathrm{~T}_{1} \mathrm{O}_{2}, 0.2 \% \mathrm{Na}_{2} \mathrm{O}, 0.1 \% \mathrm{CaO}$, $0.08 \% \mathrm{~B}_{2} \mathrm{O}_{3}$, trace $\mathrm{MgO}$.

also observed. Unifelt 2600 contained a considerable amount of glassy phase and crystalline phases included $\alpha-\mathrm{Al}_{2} \mathrm{O}_{3}$ (corundum), $\delta-\mathrm{Al}_{2} \mathrm{O}_{3}, \mathrm{SiO}_{2}$, $\mathrm{Al}_{2} \mathrm{SiO}_{5}, \mathrm{Na}_{6} \mathrm{Al}_{4} \mathrm{Si}_{4} \mathrm{O}_{17}$, and $\mathrm{LHOH}$. Other peaks were observed but could not be identified. Kaowool was predominantly glassy with a few very minor peaks. No crystalline phases could be identified with certainty.

\section{Scanning Electron Microscopy}

Scanning electron microscopy was used to examine the structure of these fibrous insulations in the as-recelved condition and after ignition of the organic binder. There was some indication of the organic binder in the as-received material but not in the ignited material. A small amount of flaky materlal was seen in the Unffelt 2600 and Unifelt 3000, but differences in composition between these particulates and the fibers could not be detected by the nondispersive detector.

Measurements of the fiber diameters taken from the photomicrographs are summarized in Table 3. The Unifelt 3000 structure was fairly uniform, and the fibers were randomly oriented. Fiber diameters ranged from 3.6 to 
Table 3. Summary of Fiber Size Distribution for Fibrous Insulations

\begin{tabular}{lcccc}
\hline & & \multicolumn{2}{c}{ Fiber } & Diameter $(\mu \mathrm{m})$ \\
\cline { 5 - 6 } Material & Fibers Measured & Range & Mean & $\begin{array}{l}\text { Standard } \\
\text { Deviation }\end{array}$ \\
\hline Unifelt 3000 & 21 & $3.6-14.1$ & 6.2 & 2.24 \\
Unifelt 2600 & 24 & $2.3-9.6$ & 5.0 & 1.94 \\
Kaowool & 11 & $1.4-7.5$ & 4.6 & 1.94 \\
\hline
\end{tabular}

14.1 $\mu \mathrm{m}$, with very few fibers in the upper end of this range. Similar results were found with the Unifelt 2600, where fiber diameters varied from 2.3 to $9.6 \mathrm{\mu m}$. Kaowool fiber diameters ranged from 1.4 to $7.5 \mathrm{\mu m}$. The fibers were much less randomly oriented, and the material had a higher number of flaky particulates.

Ignition Tests and Density Measurements

The organic binder used in the manufacture of the Unifelt boards burns off after heating for several hours at $400^{\circ} \mathrm{C}$, resulting in a weight loss and subsequent density decrease. Typical results are summarized in Table 4. Stability in the lateral dimensions was good, with no measurable changes observed. However, expansion across the thickness occurred, further decreasing the density.

Ignition temperatures of 400 or $500^{\circ} \mathrm{C}$ produced little difference in final density or weight loss, although the specimens ignited at $400^{\circ} \mathrm{C}$ were often off-white to gray, suggesting incomplete ignition. Because of this, all subocquent opccimens were ignited at $500^{\circ} \mathrm{C}$. 
Table 4. Results from Ignition Tests and Density Measurements

\begin{tabular}{|c|c|c|c|}
\hline \multirow{2}{*}{$\begin{array}{l}\text { Ignition } \\
\text { Temperature } \\
\left({ }^{\circ} \mathrm{C}\right)\end{array}$} & \multicolumn{2}{|c|}{ Density $\left[\mathrm{Mg} / \mathrm{m}^{3}\left(1 \mathrm{~b} / \mathrm{ft} \mathrm{t}^{3}\right)\right]$} & \multirow{2}{*}{$\begin{array}{l}\text { Weight Loss } \\
\text { on Ignition } \\
(\%)\end{array}$} \\
\hline & Initial & Final & \\
\hline \multicolumn{4}{|c|}{ Unifelt 3000} \\
\hline $\begin{array}{l}400 \\
500\end{array}$ & $\begin{array}{l}0.119(7.4) \\
0.119(7.4)\end{array}$ & $\begin{array}{l}0.085(5.3) \\
0.088(5.5)\end{array}$ & $\begin{array}{l}6.4 \\
6.3\end{array}$ \\
\hline \multicolumn{4}{|c|}{ Unifelt 2600} \\
\hline $\begin{array}{l}400 \\
500\end{array}$ & $\begin{array}{l}0.146(9.1) \\
0.147(9.2)\end{array}$ & $\begin{array}{ll}0.112 & (7.0) \\
0.122 & (7.6)\end{array}$ & $\begin{array}{l}7.3 \\
7.2\end{array}$ \\
\hline \multicolumn{4}{|c|}{ Ka nwon 1} \\
\hline 500 & $0.128(8.0)$ & $0.127(7.9)$ & 0.2 \\
\hline
\end{tabular}

Res111ence Tests

Data obtained from the resilience tests are summarized in Table 5. According to the arbitrary criterion of $90 \%$ resilience or greater after $20 \mathrm{~h}$ at $816^{\circ} \mathrm{C}\left(1500^{\circ} \mathrm{F}\right)$ that has been established for acceptance, Unifelt 3000 is acceptable, Unifelt 2600 is a marginal, and the Kaowool is definitely unacceptable.

Table 5. Resilience Test Data for Fibrous Insulations

\begin{tabular}{|c|c|c|c|c|}
\hline \multirow[b]{2}{*}{ Material } & \multicolumn{3}{|c|}{ Resiliance, \% } & \multirow[b]{2}{*}{ Epecimeno } \\
\hline & Mean & Range & $\begin{array}{l}\text { Standard } \\
\text { Deviation }\end{array}$ & \\
\hline UnIfe1L $3000^{\alpha}$ & 97.3 & $95.5-100.4$ & 1.92 & 8 \\
\hline Unifelt $2600^{a}$ & 88.3 & $85.7-88.8$ & 1.19 & 8 \\
\hline Ka owo o1 ${ }^{a}$ & 76.2 & $75.6-77.2$ & 0.45 & 8 \\
\hline Unifelt $3000^{b}$ & 87.1 & $85.4-88.8$ & 2.40 & 2 \\
\hline Unifelt $2600^{b}$ & 76.5 & $75.6-77.4$ & 1.27 & 2 \\
\hline
\end{tabular}

$a_{\text {After }} 20 \mathrm{~h}$ at $816^{\circ} \mathrm{C}\left(1500^{\circ} \mathrm{F}\right)$.

$b_{\text {After }} 20 \mathrm{~h}$ at. $982^{\circ} \mathrm{C}\left(1800^{\circ} \mathrm{F}\right)$. 
Helium Perneation

Data obtained from the helium permeation tests are suminarized in Table 6 and Fig. 2. In Table 6, the flow rate at 6.895-kPa (1-psi) pressure is given at various compressed densities. This pressure is the

Table 6. Helium Permeation as a Function of Compressed Density

\begin{tabular}{|c|c|c|c|c|}
\hline \multirow{2}{*}{$\begin{array}{l}\text { Compressed } \\
\left(\mathrm{Mg} / \mathrm{m}^{3}\right)\end{array}$} & \multirow{2}{*}{$\begin{array}{l}\text { Density } \\
\left(1 \mathrm{~b} / \mathrm{ft}^{3}\right)\end{array}$} & \multicolumn{3}{|c|}{ Helium Perneation $a\left[10^{-4} \mathrm{~m}^{3} / \mathrm{s}(\operatorname{scfm})\right]$} \\
\hline & & Unifelt 3000 & Unifelt 2600 & Kaowool \\
\hline 0 . & $(\varepsilon$ & $5.95(1.26)$ & & \\
\hline 0.144 & ( & $5.66(1.20)$ & $6.09(1.29)$ & $6.28)$ \\
\hline 0.160 & $(10$. & $5.43(1.15)$ & $5.80(1.23)$ & $6.11(1.30)$ \\
\hline & (11. & $5.14(1.09)$ & $5.50(1.16)$ & $5.92(1.26)$ \\
\hline 0.192 & $(12.0)$ & $4.86(1.03)$ & $5.31(1.12)$ & $5.78(1.22)$ \\
\hline
\end{tabular}

$a_{\text {At }} 6.895 \mathrm{kPa}$ (1 psi).

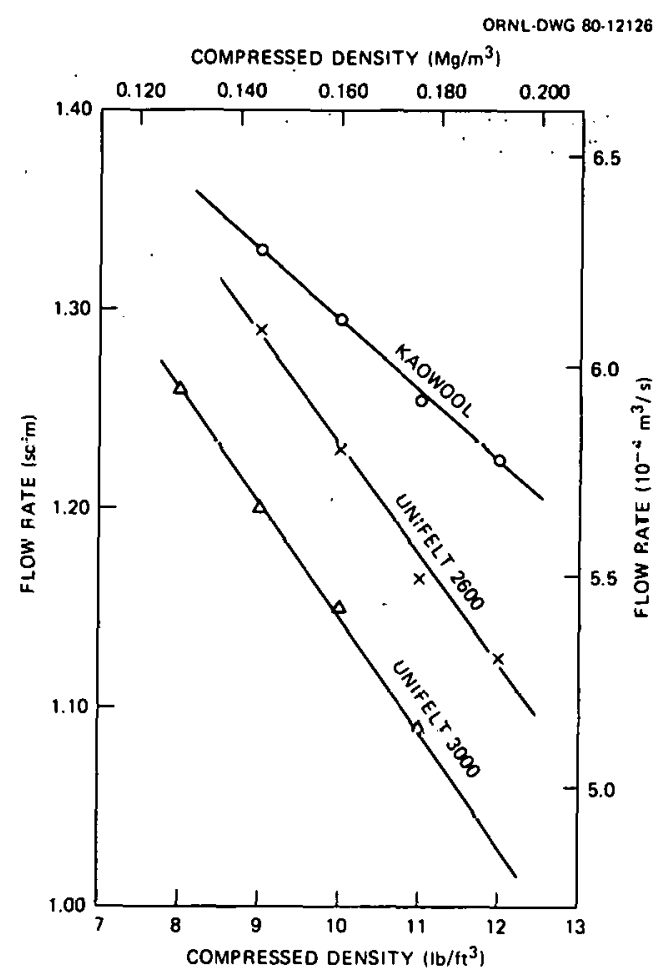

Fig. 2. Helium Perneation at. $6.895 \mathrm{kPa}$ ( 1 psi) as a Function of Compressed Density. 
net pressure after the line losses are subtracted from the total recorded pressure. Line losses were determined by measuring the pressure difference $\Delta p(\sim 100 \mathrm{~mm} \mathrm{H} 2)$ at a flow rate of about $4.7 \times 10^{-4} \mathrm{~m}^{3} / \mathrm{s}(1 \mathrm{scfm})$. A pressure of $100 \mathrm{~mm} \mathrm{H}_{2} \mathrm{O}$ equals $0.986 \mathrm{kPa}(0.143 \mathrm{psi})$. Therefore, plots of the flow rate as a function of $\Delta p$ were extrapolated to $7.881 \mathrm{kPa}$ ( $1.143 \mathrm{psi}$ ) to obtain the flow rate at a net $\Delta p$ of $6.895 \mathrm{kPs}$ ( 1 psi).

\section{Compressive Stress-Strain}

Results from the compressive stress-strain measurements are summarized in Tables 7 to 9 and Figs. 3 to 5. Figure 3 shows similar results with Unifelt 3000 on samples run before and after the resilience tests. Some unaccountable scatter exists in the data. Table 7 indicates some permanent deformation of the material which may account for some of the deviations, but the problem has not been resolved.

Table 7. Compressive Properties of Ignited ${ }^{a}$ Unifelt 3000 Fibrous Insulation Board

\begin{tabular}{llcc}
\hline Starting & Ampunt nf & Compressive & Compressiul \\
Thickness & Compression & Stress & $(\%)$ \\
{$[\mathrm{mm}$ (in.) $]$} & {$[\mathrm{mm}$ (in.) $]$} & {$[\mathrm{kPa}(\mathrm{psi})]$} & $(\%)$ \\
\hline
\end{tabular}

As Ignited

\begin{tabular}{lrrrr}
$84.1(3.31)$ & $41.3(1.62)$ & $6.06(0.88)$ & 49.0 \\
$69.8(2.75)$ & $30.2(1.19)$ & $9.03(1.31)$ & 43.3 \\
$70.6(2.78)$ & $33.8(1.33)$ & $11.67(1.69)$ & 47.8 \\
$59.5(2.34)$ & $28.9(1.14)$ & $14.41(2.09)$ & 48.6 \\
\multicolumn{5}{c}{ Resilience Tested at $816^{\circ} \mathrm{C}\left(1500^{\circ} \mathrm{F}\right)$} \\
\\
$76.2(3.00)$ & $32.5(1.28)$ & $6.89(1.00)$ & 42.5 \\
$69.8(2.75)$ & $33.0(1.30)$ & $10.20(1.48)$ & 47.2 \\
$68.1(2.68)$ & $33.0(1.30)$ & $13.30(1.93)$ & 48.5 \\
$57.9(2.28)$ & $24.9(0.98)$ & $16.48(2.39)$ & 43.0 \\
\multicolumn{5}{c}{ Resilience Tested at $982^{\circ} \mathrm{C}\left(1800^{\circ} \mathrm{F}\right)$} \\
\\
$69.8(2.75)$ & $29.0(1.14)$ & $7.38(1.07)$ & 41.4 \\
$70.1(2.76)$ & $34.0(1.34)$ & $10.89(1.58)$ & 48.5 \\
$70.6(2.78)$ & $36.3(1.43)$ & $14.62(2.12)$ & 51.5 \\
$70.1(2.76)$ & $48.8(1.92)$ & $18.20(2.64)$ & 69.6
\end{tabular}

$a_{\text {Ignited }} 4 \mathrm{~h}$ at $500^{\circ} \mathrm{C}$. 
Table 8. Compressive Properties of Ignited Unifelt 2600 Fibrous Insulation Board

\begin{tabular}{|c|c|c|c|c|}
\hline $\begin{array}{l}\text { Star } \\
\text { Thic } \\
{[\mathrm{mm}}\end{array}$ & $\begin{array}{l}\text { rting } \\
\text { ckness } \\
\text { (in.)] }\end{array}$ & $\begin{array}{l}\text { Amount of } \\
\text { Compression } \\
\text { [mm (in.)] }\end{array}$ & $\begin{array}{l}\text { Compressive } \\
\text { Stress } \\
{[\mathrm{kPa}(p s i)]}\end{array}$ & $\begin{array}{c}\text { Compression } \\
(\%)\end{array}$ \\
\hline \multicolumn{5}{|c|}{ As Ignited } \\
\hline $\begin{array}{l}63.5 \\
59.2 \\
65.8 \\
66.5\end{array}$ & $\begin{array}{l}(2.50) \\
(2.33) \\
(2.59) \\
(2.62)\end{array}$ & $\begin{array}{l}14.7(0.58) \\
19.3(0.76) \\
23.4(0.92) \\
26.4(1.04)\end{array}$ & $\begin{aligned} 6.14 & (0.89) \\
9.17 & (1.33) \\
12.13 & (1.76) \\
16.13 & (2.34)\end{aligned}$ & $\begin{array}{l}23.4 \\
32.4 \\
35.4 \\
39.4\end{array}$ \\
\hline \multicolumn{5}{|c|}{ Resilience Tested at $816^{\circ} \mathrm{C}\left(1500^{\circ} \mathrm{F}\right)$} \\
\hline $\begin{array}{l}66.8 \\
69.3 \\
67.8 \\
68.1\end{array}$ & $\begin{array}{l}(2.63) \\
(2.73) \\
(2.67) \\
(2.68)\end{array}$ & $\begin{array}{l}22.4(0.88) \\
28.2(1.11) \\
29.2(1.15) \\
30.2(1.19)\end{array}$ & $\begin{aligned} 6.76 & (0.98) \\
10.20 & (1.48) \\
13.37 & (1.94) \\
16.54 & (2.40)\end{aligned}$ & $\begin{array}{l}33.5 \\
42.1 \\
42.0 \\
44.5\end{array}$ \\
\hline \multicolumn{5}{|c|}{ Resilience Tested at $982^{\circ} \mathrm{C}\left(1800^{\circ} \mathrm{F}\right)$} \\
\hline $\begin{array}{l}54.6 \\
55.1 \\
58.9 \\
58.7\end{array}$ & $\begin{array}{l}(2.15) \\
(2.17) \\
(2.32) \\
(2.31)\end{array}$ & $\begin{array}{l}11.4(0.45) \\
15.0(0.59) \\
21.3(0.84) \\
23.1(0.91)\end{array}$ & $\begin{aligned} 7.03 & (1.02) \\
10.48 & (1.52) \\
13.86 & (2.01) \\
17.37 & (2.52)\end{aligned}$ & $\begin{array}{l}21.0 \\
27.2 \\
36.2 \\
39.4\end{array}$ \\
\hline
\end{tabular}

Table 9. Compressive Properties of Ignited Kaowool Fibrous Insulation Blanket

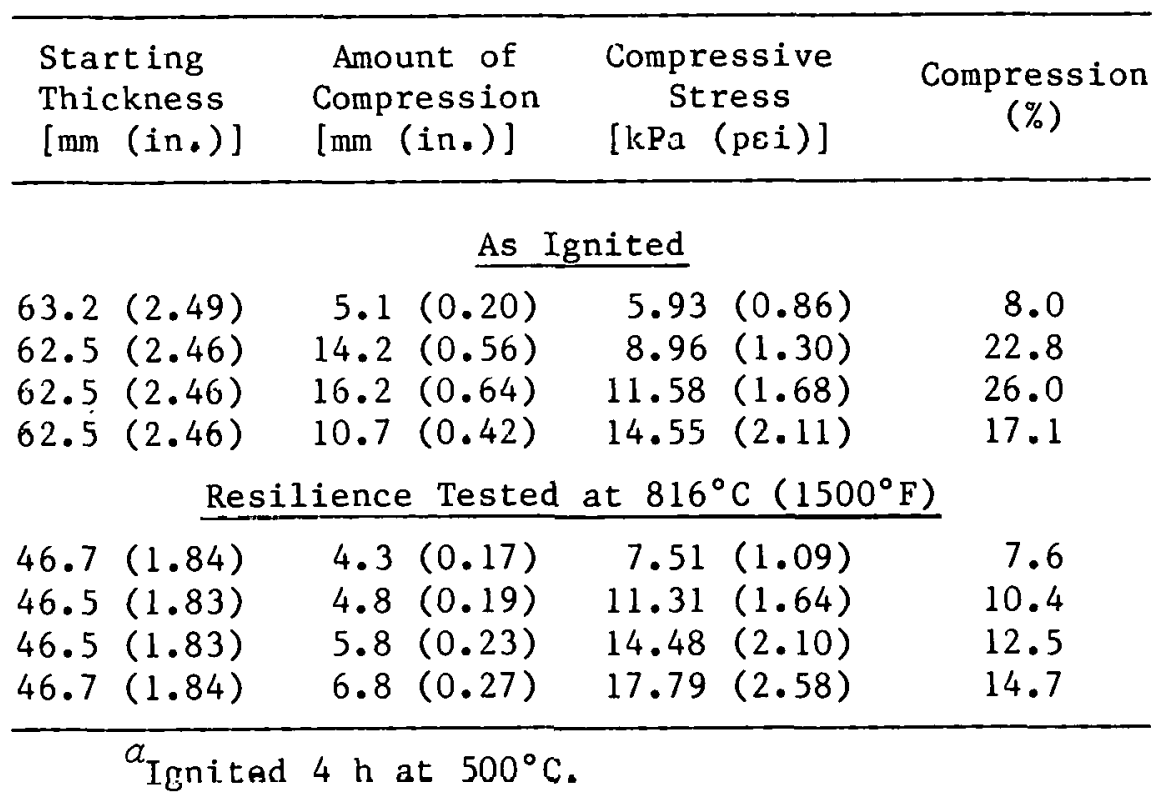




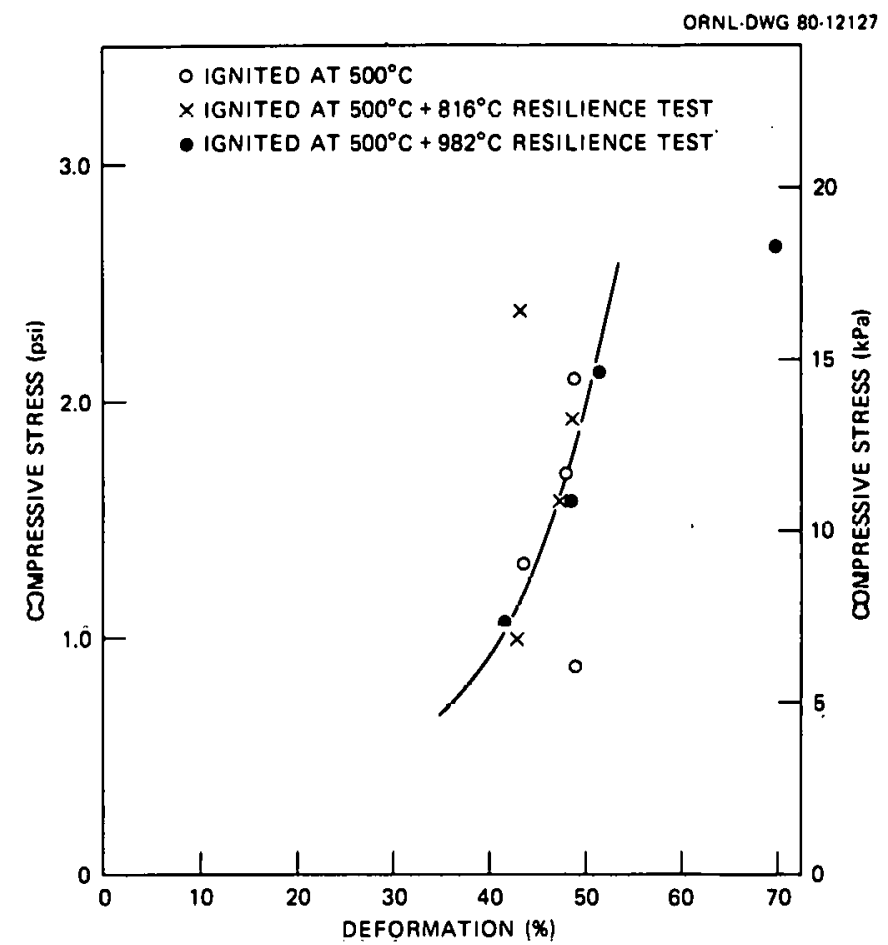

Fig. 3. Compressive Properties of Unifelt 3000.

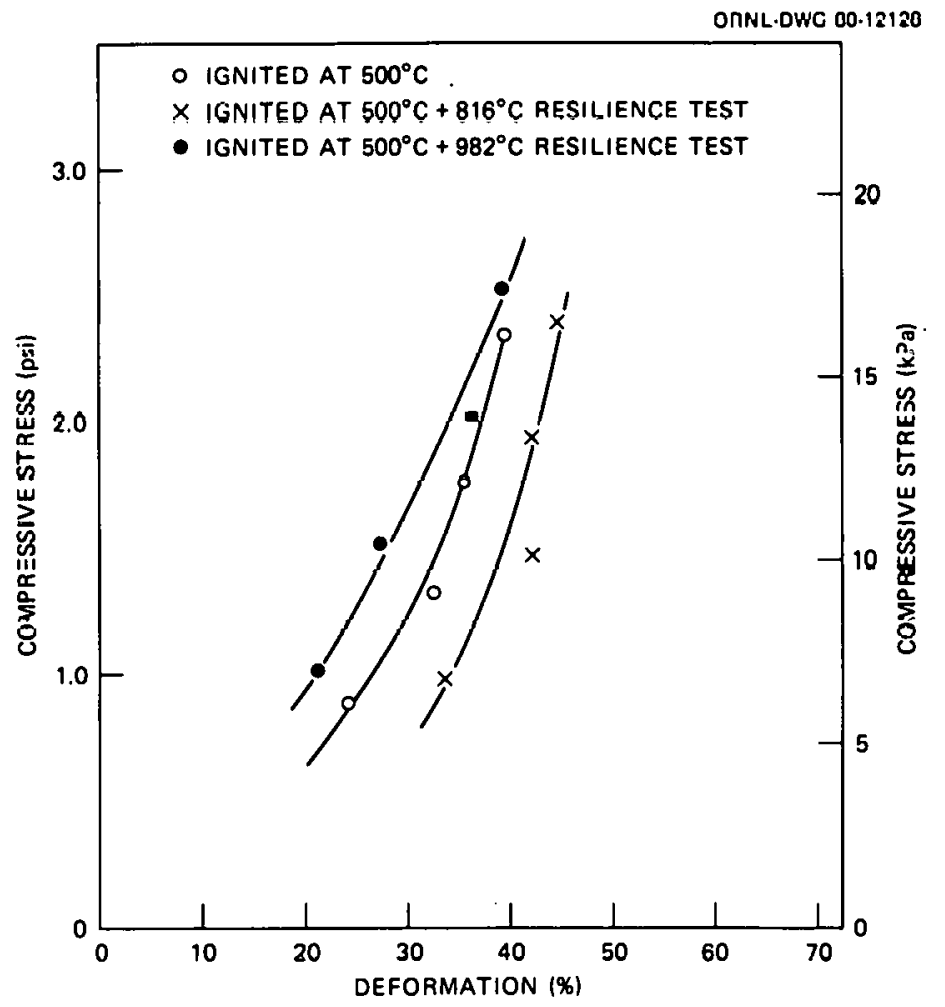

Fig. 4. Compressive Properties of Unifelt 2600. 


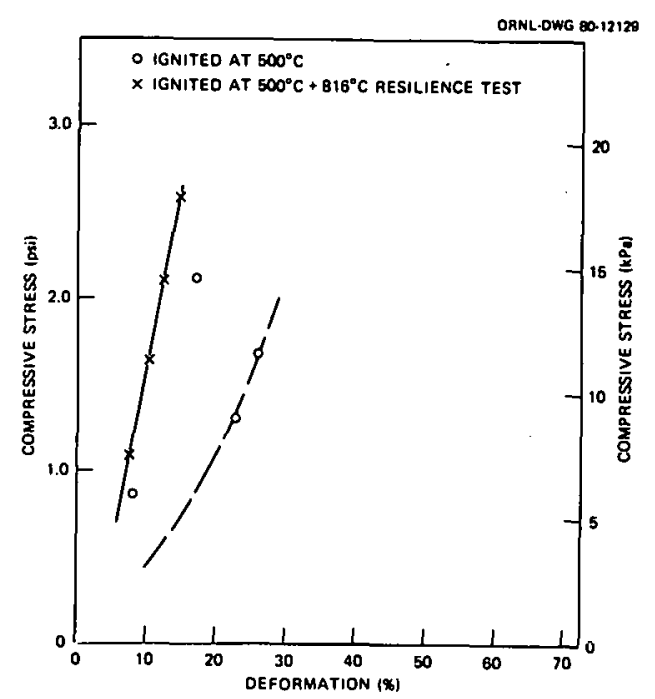

Fig. 5. Compressive Properties of Kaowool.

The data for Unifelt 2600 are fairly consistent and indicate that after the $816^{\circ} \mathrm{C}$ resilience test the material deforms more under a given load than the ignited material, while after the $982^{\circ} \mathrm{C}$ resilience test the material deforms less.

Kaowool tested after ignition at $500^{\circ} \mathrm{C}$ gave rather erratic results, but after resilience testing very consistent data were obtained.

Data taken fron the figures at $10.34 \mathrm{kPa}(1.5 \mathrm{psi})$ are summarized in Table 10, which gives the amount of compression obtained at $10.34 \mathrm{kPa}$ ( 1.5 psi) for the various materials and conditions. This table supports the observations made above.

Table 10. Compression Obtained at $10.34 \mathrm{kPa}$ ( $1.5 \mathrm{psi})$ on Fibrous Insulations

\begin{tabular}{lccc}
\hline & \multicolumn{3}{c}{ Compression, \% } \\
\cline { 2 - 4 } Condition & Unifelt 3000 & Unifelt 2600 & Kaowool \\
\hline $\begin{array}{l}\text { Ignited at } 500^{\circ} \mathrm{C} \\
\begin{array}{l}\text { Ignited at } 500^{\circ} \mathrm{C} \\
\text { plus } 816^{\circ} \mathrm{C} \mathrm{re-} \\
\text { silience test }\end{array}\end{array}$ & 46.5 & 33.0 & 24.5 \\
$\begin{array}{l}\text { Ignited at } 500^{\circ} \mathrm{C} \\
\text { plus } 982^{\circ} \mathrm{C} \mathrm{re-} \\
\text { silienr.e test }\end{array}$ & 46.5 & 39.5 & 9.5 \\
\hline
\end{tabular}


CONCLUSIONS

Three B\&W fibrous insulations (Unifelt 3000 board, Unifelt 2600 board, and Kaowool blanket) have been characterized for consideration as thermal insulation for potential HTGR application.

Based on the resilience test, the Unifelt 3000 is acceptable, the Unifelt 2600 is marginal, and the Kaowool is unacceptable. Since the Unifelt 2600 is close to the acceptable criterion for resilience ( 88.3 vs $90 \%)$, it may be useful, particularly in view of the fact that its other properties are similar to those for Unifelt 3000. It is a 1ittle easier to handle, has less tendency for delamination, and costs much less ( $\$ 13$ vs $\left.\$ 31 / \mathrm{ft}^{2}\right)$. Since maintenance of acceptable resilience is critical for fibrous insulations in HTGR application, aging effects on this characteristic must be known. Aging tests are being conducted on both Unifelt insulations. Specimens for these tests were compressed in the same manner as for the 20-h resilience tests and will be aged for periods of $3,6,12$, and 24 months at $816^{\circ} \mathrm{C}\left(1500^{\circ} \mathrm{F}\right)$, after which resilience measurements will be made. Results of these tests will be reported later.

\section{ACKNOWLEDGMENTS}

The author would like to express appreclation to V. J. Tennery and to J. C. Sheehan of General Atomic Company, La Jolla, California, for helpful suggestions in planning this work, to J. F. Willmering for specimen preparation, to J. C. Feltner for compression tests, to T. J. Henson for SEM examinations, to 0 . B. Cavin for x-ray diffraction analysis, to R. L. Beatty and T. N. Tiegs for technical review, to Myrtleen Sheldon for editorial review, and Kathryn A. Witherspoon for report preparation.

\section{REFERENCES}

1. K. Koyama, Properties of Ceramic Fiber Matorials for Class B Thermal. Thermal Barrier Applications, GA-D-13939 (July 1976).

2. General Atomic Company, HTGR Generic Technology Programs, Semiannu. Prog. Rep. Mar. 31, 1979, GA-A-1517, pp. 10-24. 
APPENDIX A

X-Ray Diffractometry Results 


\section{THIS PAGE WAS INTENTIONALLY LEFT BLANK}




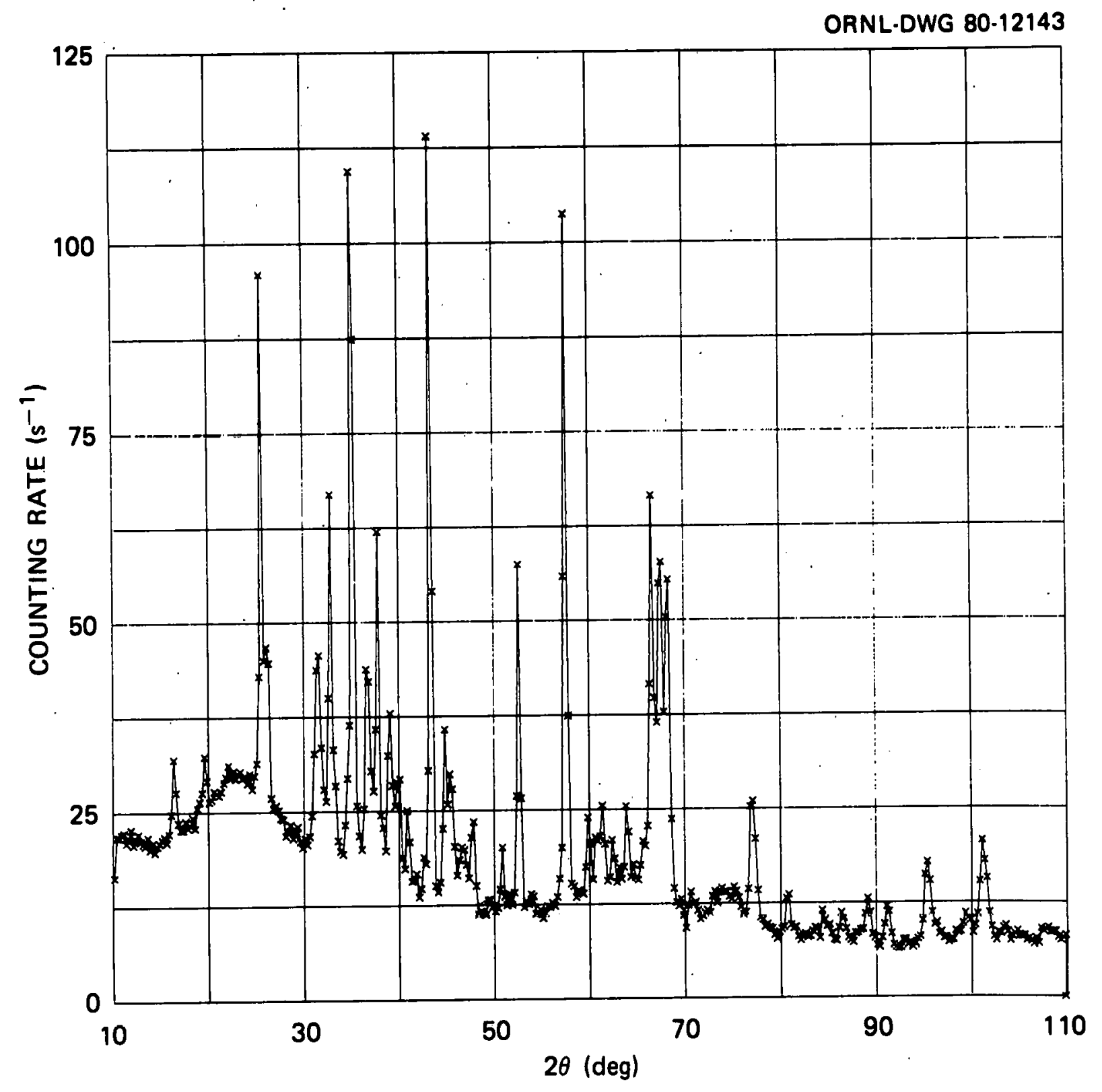

F1g. A.1. Results of X-Ray Diffractometry Tests on Unifelt 3000. Points represent average of ten measurement. 


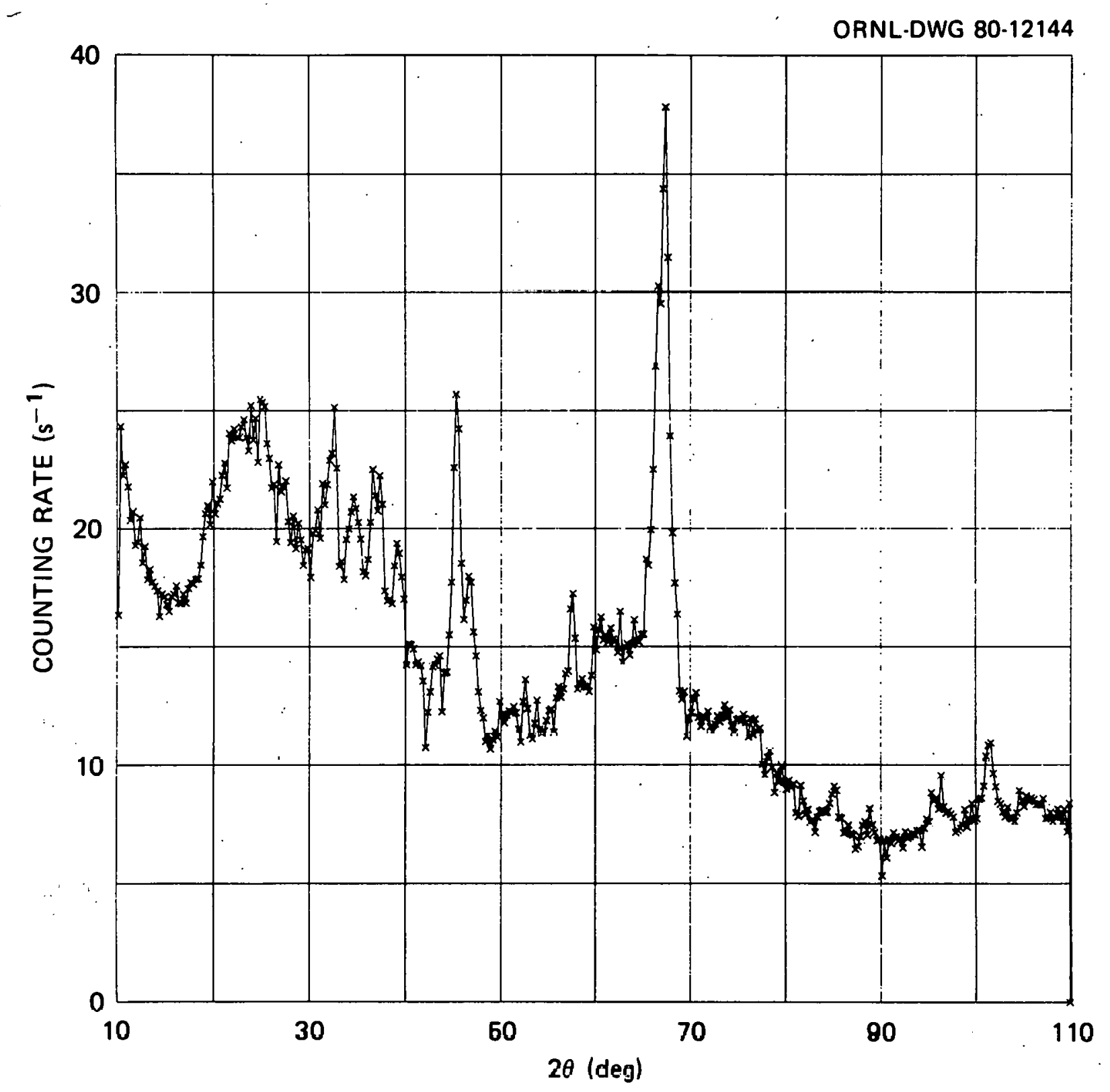

F1g. A.2. Results of X-Ray Diffractometry Tests on Unifelt 2600. Points represent average of ten measurement. 


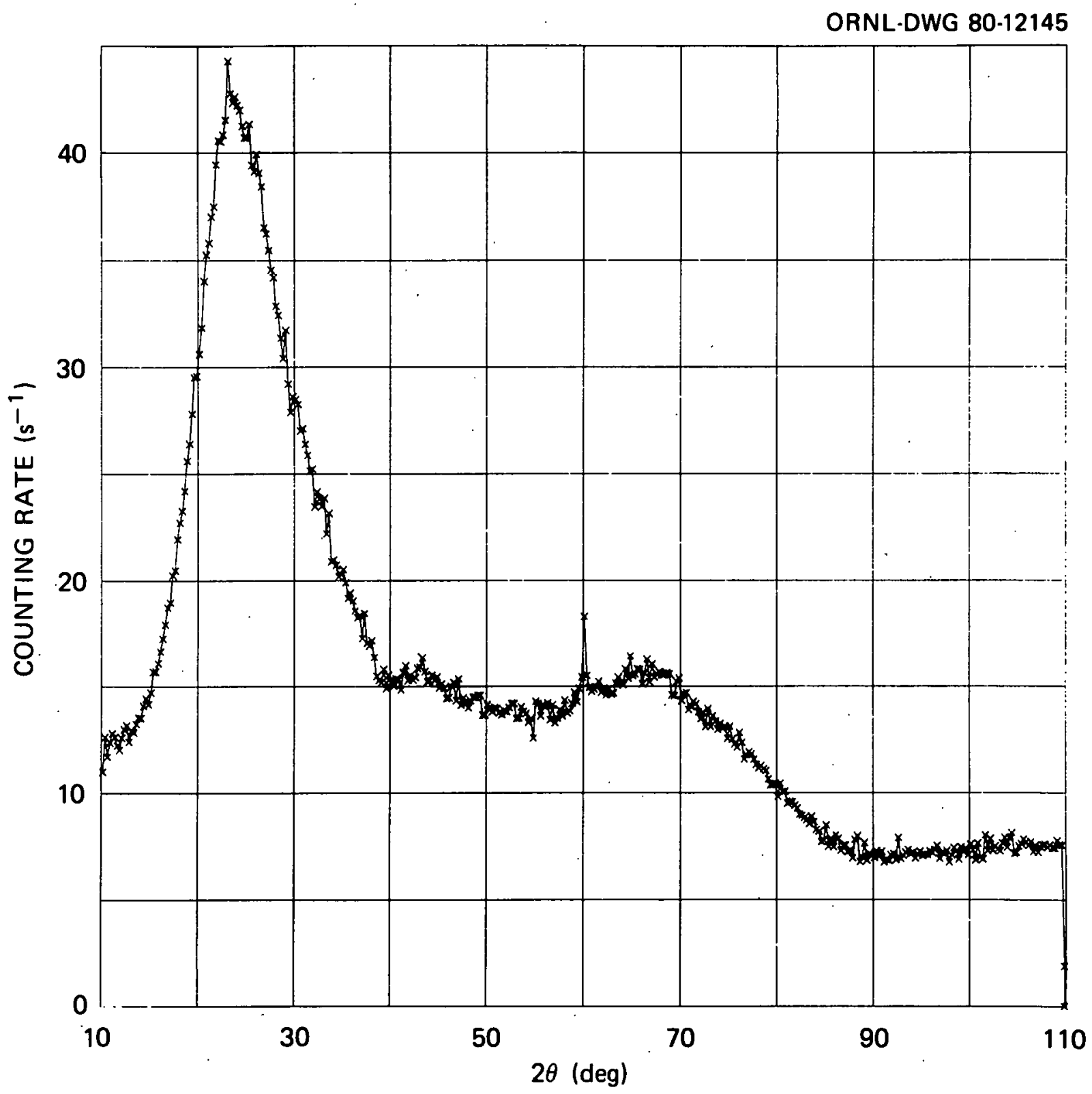

Fig. A.3. Results of X-Ray Diffractometry Tests on Koawool. Points represent average of 20 measurement. 
Table A.1. d-Spacings for Peaks in Fig. A.1 - Urifelt 3000

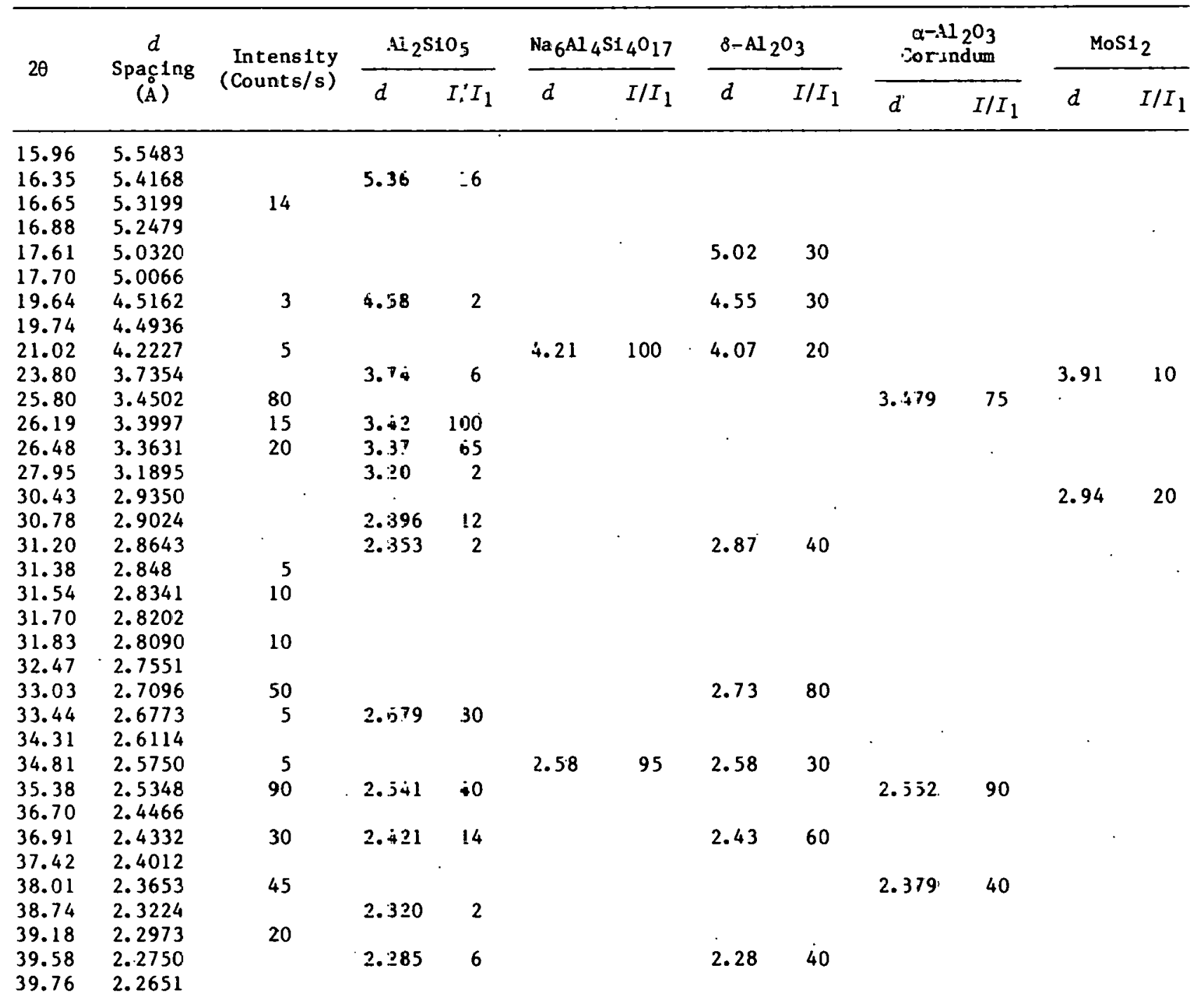


Table A.1. (Continued)

\begin{tabular}{|c|c|c|c|c|c|c|c|c|c|c|c|c|}
\hline \multirow{2}{*}{$2 \theta$} & \multirow{2}{*}{$\begin{array}{c}d \\
\text { Spacing } \\
(\AA)\end{array}$} & \multirow{2}{*}{$\begin{array}{l}\text { Intensity } \\
\text { (Counts/s) }\end{array}$} & \multicolumn{2}{|c|}{$\mathrm{Al}_{2} \mathrm{SiO}_{5}$} & \multicolumn{2}{|c|}{$\mathrm{Na}_{6} \mathrm{Al}_{4} \mathrm{Si}_{4}{ }^{\mathrm{O}} 17$} & \multicolumn{2}{|c|}{$8-\mathrm{Al}_{2} \mathrm{O}_{3}$} & \multicolumn{2}{|c|}{$\begin{array}{r}\alpha-\mathrm{Al}_{2} \mathrm{O}_{3} \\
\text { Corundum }\end{array}$} & \multicolumn{2}{|c|}{$\operatorname{MoS1}_{2}$} \\
\hline & & & $d$ & $I / I_{1}$ & $d$ & $I / I_{1}$ & $d$ & $I / I_{1}$ & $d$ & $I / I_{1}$ & $d$ & $I / I_{1}$ \\
\hline 40.20 & 2.2413 & 20 & & & & & & & & & 2.24 & 50 \\
\hline 40.63 & 2.2186 & & & & & & & & & & & \\
\hline 40.88 & 2. 2056 & & 2.204 & 60 & & & & & . & & & \\
\hline $\begin{array}{l}41.13 \\
41.66\end{array}$ & $\begin{array}{l}2.1928 \\
2.1661\end{array}$ & 15 & & & & & & & & & & \\
\hline 41.66 & 2.1661 & & & & & & & & 2.165 & $<1$ & & \\
\hline 41.95 & 2.1518 & & & & & & & & & & & \\
\hline 42.29 & 2.1353 & & & & & & · & & & & & \\
\hline 42.87 & 2.1077 & 5 & 2.111 & 20 & 2.103 & 8 & & & & & & \\
\hline 43.59 & 2. 0746 & 140 & & & & & & & 2.085 & 100 & & \\
\hline 44.42 & 2.0377 & & & & & & & & & & & \\
\hline 45.01 & 2.0123 & 15 & & & & & & & & & 2.01 & 60 \\
\hline 45.63 & 1.9864 & 12 & & & & & 1.99 & 80 & & & & \\
\hline 45.84 & 1.9778 & & & & & & & & & & & \\
\hline 46.30 & 1.9592 & & & & & & & & 1.964 & 2 & & \\
\hline 46.53 & 1.9501 & & & & & & 1.95 & 30 & & & & \\
\hline $\begin{array}{l}46.75 \\
46.92\end{array}$ & 1.9414 & 5 & & & & & & & & . & 1.94 & 20 \\
\hline $\begin{array}{l}46.92 \\
47.13\end{array}$ & 1.9348 & & & & & & & & , & & & \\
\hline 47.13 & 1.9267 & & & & . & & & & & & & \\
\hline 47.55 & 1.9106 & & & & & & 1.91 & 20 & & & & \\
\hline 47.94 & 1.8960 & 15 & & & & & & & & & & \\
\hline 48.25 & 1.8845 & & 1.867 & 6 & & & & & & & & \\
\hline 49.92 & 1.8253 & . & 1.830 & 2 & & & & & & & & \\
\hline 50.06 & 1.8205 & & & & 1.821 & 16 & & & & & & \\
\hline 50.21 & 1.8154 & & 1.817 & 2 & & & & & & & & \\
\hline 50.63 & 1.8014 & & & & & & 1.80 & 20 & & & & \\
\hline 50.99 & 1.7895 & 12 & 1.786 & 4 & & & & & & & & \\
\hline 51.86 & 1.7615 & & & & & & & & & & & \\
\hline 51.99 & 1.7574 & & & & & & & & & & & \\
\hline 52.81 & 1.7320 & 57 & & & & & & & 1.740 & 45 & & \\
\hline 54.25 & 1.6894 & & 1.682 & 12 & 1.669 & 4 & & & & & & \\
\hline 57.75 & 1.5951 & 120 & 1.597 & 8 & & & & & 1.601 & 80 & 1.59 & 25 \\
\hline 58.84 & 1.5681 & & 1.570 & 2 & & & & & & & & \\
\hline 59.19 & 1.5596 & & 1.563 & 2 & & & & & & & & \\
\hline 60.11 & 1.5380 & 12 & & & & & 1.54 & 40 & 1.546 & 4 & & \\
\hline
\end{tabular}


Table A.1. (Continued)

\begin{tabular}{|c|c|c|c|c|c|c|c|c|c|c|c|c|}
\hline \multirow{2}{*}{$2 \theta$} & \multirow{2}{*}{$\begin{array}{c}d \\
\text { Spacing } \\
(\AA)\end{array}$} & \multirow{2}{*}{$\begin{array}{l}\text { Intensity } \\
\text { (Counts/s) }\end{array}$} & \multicolumn{2}{|c|}{$\mathrm{Al}_{2}-\mathrm{S}_{5} \mathrm{~J}_{5}$} & \multicolumn{2}{|c|}{$\mathrm{Na}_{6} \mathrm{Al}_{4} \mathrm{Si}_{4} \mathrm{O}_{17}$} & \multicolumn{2}{|c|}{$\delta-\mathrm{Al}_{2}{ }^{\mathrm{O}_{3}}$} & \multicolumn{2}{|c|}{$\begin{array}{r}x-\mathrm{Al}_{2} \mathrm{O}_{3} \\
\text { Corundum }\end{array}$} & \multicolumn{2}{|c|}{$\mathrm{MoSi}_{2}$} \\
\hline & & & 1 & $I / I_{1}$ & $d$ & $I / I_{1}$ & $d$ & $I / I_{1}$ & $d$ & $I / I_{1}$ & $d$ & $I / I_{1}$ \\
\hline $\begin{array}{l}60.57 \\
60.69 \\
60.88\end{array}$ & $\begin{array}{l}1.5274 \\
1.5246 \\
1.5203\end{array}$ & & & & & & & & & & & \\
\hline 61.00 & 1.5176 & 7 & 1.519 & 2 & & & & & & & & \\
\hline 61.19 & 1.5134 & & & & & & 1.51 & 30 & 1.5114 & 6 & & \\
\hline 61.57 & 1.5049 & 10 & & & & & & & 1.510 & 8 & & \\
\hline 62.16 & 1.4921 & & & & & & 1.49 & 40 & & & & \\
\hline $62.57^{\circ}$ & 1.4833 & 5 & & & 1.486 & 30 & & & & & & \\
\hline 62.70 & 1.4805 & 5 & & & & & & & & & & \\
\hline 62.88 & 1.4767 & & & & & & & & & & & \\
\hline 63.02 & 1.4738 & & & & & & & & & & & \\
\hline 63.16 & 1.4708 & & & & & & & & & & & \\
\hline 63.33 & 1.4673 & & & & & & & & & & & \\
\hline 63.74 & 1.4588 & & & & & & & & & & 1.46 & 20 \\
\hline 64.10 & 1.4515 & 10 & & & & & 1.45 & 30 & & & & \\
\hline 64.27 & 1.4481 & & & & . & & & & & & & \\
\hline 64.83 & 1.4369 & & & & & & & & & & & \\
\hline 65.06 & 1.4324 & & & & & & & & & & & \\
\hline 65.20 & 1.4297 & & & & & & & & & & & \\
\hline 65.40 & 1.4258 & & & & & & & & & & & \\
\hline 65.81 & 1.4179 & 4 & & & & & & & & & & \\
\hline 66.00 & 1.4142 & & & & & & & & & & & \\
\hline 66.22 & 1.4101 & & & & & & & & & & & \\
\hline 66.77 & 1.3998 & 50 & & & 1.404 & 4 & 1.40 & 60 & $1 .+194$ & 30 & & \\
\hline 67.35 & 1.3891 & & & & & & 1.39 & 100 & & & 1.39 & 25 \\
\hline 67.61 & 1.3844 & 5 & & & & & & & & & & \\
\hline 67.69 & 1.3830 & 35 & & & & & & & & & & \\
\hline 67.79 & 1.3812 & 5 & & & & & . & & & & & \\
\hline 68.45 & 1.3695 & 40 & . & & & & & & 1.374 & 50 & & \\
\hline 69.07 & 1.3587 & & & & & & & & & & & \\
\hline 69.26 & 1.3554 & & & & & & & & & & & \\
\hline 70.01 & 1.3427 & & & & & & & & 1.337 & 2 & & \\
\hline
\end{tabular}


Table A.1. (Continued)

\begin{tabular}{|c|c|c|c|c|c|c|c|c|c|c|c|c|}
\hline \multirow{2}{*}{$2 \theta$} & \multirow{2}{*}{$\begin{array}{c}d \\
\text { Spacing } \\
(\AA)\end{array}$} & \multirow{2}{*}{$\begin{array}{l}\text { Intensity } \\
\text { (Counts/s) }\end{array}$} & \multicolumn{2}{|c|}{$\mathrm{Al}_{2} \mathrm{SiO}_{5}$} & \multicolumn{2}{|c|}{$\mathrm{Na}_{6} \mathrm{Al}_{4} \mathrm{Si}_{4} \mathrm{O}_{17}$} & \multicolumn{2}{|c|}{$\delta \div \mathrm{Al}_{2} \mathrm{O}_{3}$} & \multicolumn{2}{|c|}{$\begin{array}{r}\alpha-\mathrm{Al}_{2} \mathrm{O}_{3} \\
\text { Corundum }\end{array}$} & \multicolumn{2}{|c|}{$\operatorname{MoS1}_{2}$} \\
\hline & & & $d$ & $I / I_{1}$ & $d$ & $I / I_{1}$ & $d$ & $I / I_{1}$ & $d$ & $I / I_{1}$ & $d$ & $I / I_{1}$ \\
\hline 73.10 & 1.2934 & & & & & & & & & - & 1.30 & 15 \\
\hline 73.33 & 1.2899 & & & & & & 1.29 & 20 & & & & \\
\hline 73.48 & 1.2877 & & & & 1.287 & 10 & & & & & & \\
\hline 73.85 & 1.2821 & & & & & & & & & & & \\
\hline 73.92 & 1.2811 & & & & & & & & & & & \\
\hline 74.22 & 1.2766 & & & & & & & & 1.276 & 4 & & \\
\hline 74.61 & 1.2709 & & & & & & & & & & . & \\
\hline 75.15 & 1.2631 & & & & & & & & & & & \\
\hline 75.33 & 1.2606 & & & & & & 1.26 & 10 & & & & \\
\hline 75.69 & 1.2555 & & & & & & & & & & & \\
\hline 75.82 & 1.2536 & & & & & & & & & & & \\
\hline 75.96 & 1.2517 & & & & & & & & & & & \\
\hline 77.12 & 1.2357 & 19 & & & & & & & 1.239 & 16 & 1.24 & 100 \\
\hline 77.36 & 1.2325 & 3 & & & 1.232 & 4 & & & 1.234 & 8 & & \\
\hline 77.49 & 1.2307 & 3 & & & & & & & & & 1.23 & 8 \\
\hline 77.65 & 1.2286 & & & & & & & & & & & \\
\hline 80.59 & 1.1910 & & & & & & & & 1.1898 & 8 & & \\
\hline 80.76 & 1.1889 & & & & & & & & & . & & \\
\hline 80.97 & 1.1864 & $\dot{4}$ & & & & & & & & & & \\
\hline 81.11 & 1.1847 & & & & & & & & & & & \\
\hline 81.21 & 1.1835 & & & & & & & & & & & \\
\hline 81.38 & 1.1814 & & & & & & & & & & & \\
\hline 82.09 & 1.1730 & . & & & & & & & . & & & \\
\hline 82.75 & 1.1653 & & & & & & & & 1.1600 & $<1$ & & \\
\hline 83.90 & 1.1522 & & & & 1.152 & 10 & & & & & & \\
\hline 84.62 & 1.1443 & 2 & & & & & & & 1.1470 & 6 & & \\
\hline 84.73 & 1.1431 & & & & & & & & 1.1382 & 2 & & \\
\hline 86.57 & 1.1234 & & & & & & & & 1.1255 & 6 & & \\
\hline 86.57 & 1.1234 & & & & & & & & 1.1255 & 6 & & \\
\hline 86.70 & 1.1221 & 5 & & & & & & & 1.1246 & 4 & & \\
\hline
\end{tabular}


Table A.1. (Continued)

\begin{tabular}{|c|c|c|c|c|c|c|c|c|c|c|c|c|}
\hline \multirow{2}{*}{$2 \theta$} & \multirow{2}{*}{$\begin{array}{c}d \\
\text { Spaçing } \\
(\AA)\end{array}$} & \multirow{2}{*}{$\begin{array}{l}\text { Intensity } \\
\text { (Counts/s) }\end{array}$} & \multicolumn{2}{|c|}{$\mathrm{Al}_{2} \mathrm{SiO}_{5}$} & \multicolumn{2}{|c|}{$\mathrm{Na}_{6} \mathrm{Al}_{4} \mathrm{SI}_{4} \mathrm{O}_{17}$} & \multicolumn{2}{|c|}{$\mathrm{S}-\mathrm{Al}_{2} \mathrm{O}_{3}$} & \multicolumn{2}{|c|}{$\begin{array}{r}a-\mathrm{Al}_{2} \mathrm{O}_{3} \\
\text { Corundum }\end{array}$} & \multicolumn{2}{|c|}{$\mathrm{MoSi}_{2}$} \\
\hline & & & $d$ & $I / I_{1}$ & $d$ & $I / I_{1}$ & $d$ & $I / I_{1}$ & $d$ & $I / I_{1}$ & $d$ & $I / I_{1}$ \\
\hline $\begin{array}{l}86.90 \\
88.43\end{array}$ & $\begin{array}{l}1.1200 \\
1.1045\end{array}$ & & & & & & & & & & 1.12 & 50 \\
\hline 89.26 & 1.0964 & 5 & & & & & & & 1.0988 & 8 & & \\
\hline 89.37 & 1.0953 & & & & & & & & & & & \\
\hline 89.49 & 1.0942 & & & & & & & & & & & \\
\hline $\begin{array}{l}89.65 \\
89.72\end{array}$ & $\begin{array}{l}1.0926 \\
1.0920\end{array}$ & & & & & & & & & & & \\
\hline 91.10 & 1.0790 & & & & & & & & 1.08831 & 4 & 1.08 & 13 \\
\hline 91.37 & 1.0765 & 2 & & & & & & & 1.19781 & 8 & & \\
\hline 91.45 & 1.0758 & & & & & & & & & & & \\
\hline 91.52 & 1.0751 & & & & & & & & & & & \\
\hline 91.65 & 1.0740 & & & & & & & & & & & \\
\hline 93.10 & 1.0610 & & & & & & & & 1.0426 & & 1.05 & 30 \\
\hline 95.54 & 1.0402 & 10 & & & & & & & & & & \\
\hline $\begin{array}{l}95.80 \\
96.07\end{array}$ & $\begin{array}{l}1.0381 \\
1.0359\end{array}$ & & & & & & & & & & & \\
\hline 96.45 & 1.0328 & & & & & & & & & & & \\
\hline 98.38 & 1.0177 & & & & & & & & 1.0175 & 2 & & \\
\hline 99.52 & 1.0091 & & & & & & & & & & 1.00 & 80 \\
\hline 101.35 & 0.9956 & 12 & & & & & & & 0.7976 & 12 & & \\
\hline 101.44 & 0.9951 & & & & & & & & & & & \\
\hline 101.61 & 0.9939 & & & & & & & & & & & \\
\hline 101.70 & 0.9932 & & & & & & & . & & & & \\
\hline 101.83 & 0.9923 & & & & & & & & & & & \\
\hline 102.31 & 0.9890 & & & & & & & & a. 9819 & 4 & & \\
\hline 105.17 & 0.9698 & & & & 0.975 & 6 & & & & & 0.978 & 25 \\
\hline 108.25 & 0.9506 & & & & & & & & & & 0.972 & 25 \\
\hline 108.82 & 0.9472 & & & & & & & & & & & \\
\hline 111.42 & 0.9323 & 2 & & & & & & & & & & \\
\hline 111.70 & 0.9307 & & & & & & & & & & & \\
\hline 116.85 & 0.9041 & 3 & & & & & & & a. 9076 & 14 & & \\
\hline 118.05 & 0.8984 & & & & & & & & a. 3991 & 8 & & \\
\hline 118.28 & 0.8973 & & & & & & & & & & & \\
\hline 118.58 & 0.8959 & & & & & & & & & & 0.895 & 25 \\
\hline
\end{tabular}


Table 4.2. d-Spacings for Peaks in Fig. A.2 - Unifelt 2600

\begin{tabular}{|c|c|c|c|c|c|c|c|c|c|c|c|c|c|c|}
\hline \multirow{2}{*}{$2 \theta$} & \multirow{2}{*}{$\begin{array}{c}d \\
\text { Spacing } \\
(\AA)\end{array}$} & \multirow{2}{*}{$\begin{array}{l}\text { Intensity } \\
\text { (Counts/s) }\end{array}$} & \multicolumn{2}{|c|}{$\mathrm{Na}_{6} \mathrm{Al}_{4} \mathrm{Si}_{4}{ }_{17}$} & \multicolumn{2}{|c|}{$\mathrm{LIOH}$} & \multicolumn{2}{|c|}{$\delta-\mathrm{Al}_{2} \mathrm{O}_{3}$} & \multicolumn{2}{|c|}{$\mathrm{Al}_{2} \mathrm{SiO}_{5}$} & \multicolumn{2}{|c|}{$\mathrm{SiO}_{2}$} & \multicolumn{2}{|c|}{$\alpha-\mathrm{Al}_{2} \mathrm{O}_{3}$} \\
\hline & & & $d$ & $I / I_{1}$ & $d$ & $I / I_{1}$ & $d$ & $I / I_{1}$ & $d$ & $I / I_{1}$ & $d$ & $I / I_{1}$ & $d$ & $I / I_{1}$ \\
\hline 12.31 & 7.1840 & & & & & & & & & & & & & \\
\hline 12.97 & 6.8198 & & & & & & & & & & & & & \\
\hline 13.23 & 6.6864 & & & & & & & & & & & & & \\
\hline 13.61 & 6.5006 & & & & & & & & & & & & & \\
\hline 14.00 & 6.3203 & & & & & & & & & & & & & \\
\hline 14.78 & 5.9885 & & . & & & & & & & & & & & \\
\hline 15.55 & 5.6936 & & & & & & & & & & & & & \\
\hline 16.57 & 5.3454 & & & & & & & & 5.35 & 70 & & & & \\
\hline 17.68 & 5.0122 & & & & & & 5.02 & 30 & & & & & & \\
\hline 18.67 & 4.7486 & & & & & & & & & & & & & \\
\hline 19.18 & 4.6235 & & & & & & & & & & & & & \\
\hline 19.51 & 4.5460 & & & & & & 4.55 & 30 & 4.56 & 30 & & & & \\
\hline 19.62 & 4.5208 & & & & & & & & & & & & & \\
\hline 20.25 & 4.3815 & 3 & & & 4.37 & 90 & & & & & 4.37 & 80 & & \\
\hline 20.45 & 4.3391 & 3 & & & & & & & & & & & & \\
\hline 21.08 & 4.2108 & 5 & 4.21 & 100 & & & & & & & & & & \\
\hline 21.51 & 4.1276 & 2 & & & & & & & & & 4.118 & 100 & & \\
\hline 21.79 & 4.0752 & & & & & & & & & & & & & \\
\hline 21.83 & 4.0678 & 2 & & & & & 4.07 & 20 & $\therefore$ & & & & & \\
\hline 22.28 & 3.9867 & & & & & & & & & & & & & \\
\hline 22.45 & 3.9569 & 3 & & & & & & & & & & & & \\
\hline 22.92 & 3.8768 & 2.5 & & & & & & & & & & & & \\
\hline 23.00 & 3.8635 & 3 & & & & & & & & & 3.862 & 60 & & \\
\hline 23.85 & 3.7277 & & & & & & & & 3.73 & 50 & & & & \\
\hline 24.07 & $3.694 !$ & .2 & & & . & & & & & & & & & \\
\hline 24.22 & 3.6116 & 6 & & & & & & & & & & & & \\
\hline 25.78 & 3.4528 & 6 & & & & & & & & & 3.479 & 75 & & \\
\hline 25.98 & 3.4254 & & & & & & & & 3.41 & 90 & & & & \\
\hline 26.43 & 3.3694 & & & & & & & & 3.36 & 100 & & & & \\
\hline 27.03 & 3.2959 & & & & & & & & & & & & & \\
\hline
\end{tabular}


Table A.2. (Ccntinued)

\begin{tabular}{|c|c|c|c|c|c|c|c|c|c|c|c|c|c|c|}
\hline \multirow{2}{*}{$2 \theta$} & \multirow{2}{*}{$\begin{array}{c}d \\
\text { Spacing } \\
(\AA)\end{array}$} & \multirow{2}{*}{$\begin{array}{r}\text { Intensity } \\
\text { (Counts/s) }\end{array}$} & \multicolumn{2}{|c|}{$\mathrm{Na}_{6} \mathrm{H}_{4} \mathrm{Si}_{4} \mathrm{O}_{-} ?$} & \multicolumn{2}{|c|}{$\mathrm{LIOH}$} & \multicolumn{2}{|c|}{$\delta-\mathrm{Al}_{2} \mathrm{O}_{3}$} & \multicolumn{2}{|c|}{$\mathrm{Al}_{2} \mathrm{SiO}_{5}$} & \multicolumn{2}{|c|}{$\mathrm{SiO}_{2}}$. & \multicolumn{2}{|c|}{$\alpha-\mathrm{Al}_{2} \mathrm{O}_{3}$} \\
\hline & & & $d$ & $I / I_{1}$ & $d$ & $I / I_{1}$ & $d$ & $I / I_{1}$ & 1 & $I / I_{1}$ & $d$ & $I / I_{1}$ & $d$ & $I / I_{1}$ \\
\hline 27.35 & 3.2581 & & & & & & & & & & & & & \\
\hline 27.85 & 3.2007 & & & & & & & & 3.19 & 10 & & & & \\
\hline 28.35 & $3: 1454$ & & & & & & & & & & & & & \\
\hline 29.70 & 3.0054 & & & & & & & & & & 2.995 & 35 & & \\
\hline 30.98 & 2.8841 & & & & & & 2.87 & 40 & 2.93 & 10 & & & . & \\
\hline 31.85 & 2.8073 & & & & & & & & 2.88 & 70 & & & & \\
\hline 32.27 & 2.7717 & 5 & & & & & & & & & & & & \\
\hline 32.78 & 2.7289 & 5 & & & 2.73 & 100 & 2.73 & 80 & & & & & & \\
\hline 32.93 & 2.7176 & & & & & & & & & & & & & \\
\hline 33.03 & 2.7096 & 12 & & & & & & & & & & & & \\
\hline 33.30 & 2.6883 & & & & & & & & 2.67 & 80 & & & & \\
\hline 34.57 & 2.5924 & & & & & & & & & & & & & \\
\hline 34.81 & 2.5750 & $\epsilon$ & 2.53 & 95 & & & 2.53 & 30 & & & & & 2.552 & 90 \\
\hline 35.43 & 2.5314 & 6 & & & 2.53 & 70 & & & 2.53 & 90 & & & & \\
\hline 35.54 & 2.5238 & & & & & & & & & & 2.523 & 25 & & \\
\hline 36.57 & 2.4550 & & & & & & 2.43 & 60 & & & & & & \\
\hline 37.37 & 2.404 & 3 & & & & & & & 2.42 & 60 & & & & \\
\hline 37.55 & 2.3932 & 3 & & & & & & & & & & & 2.379 & 40 \\
\hline 38.05 & 2.3629 & & & & & & & & 2.37 & 10 & 2.325 & 20 & & \\
\hline 39.49 & 2.2800 & & & & & & 2.28 & 40 & 2.28 & 60 & & & & \\
\hline 39.62 & 2.2728 & 3 & & & & & & & & & & & & \\
\hline 40.09 & 2.2472 & & & & & & & & & & & & & \\
\hline 40.25 & 2.2387 & & & & & & & & & & & & & \\
\hline 40.50 & 2.2254 & & & & & & & & & & & & & \\
\hline 41.66 & 2.1661 & & & & 2.17 & 40 & & & & & 2.152 & 2 & 2.165 & 1 \\
\hline 42.71 & 2.1152 & & 2.103 & 8 & & & & & & & 2.114 & 8 & & \\
\hline 43.57 & 2.0755 & 8 & & & & & & & 2.09 & 30 & 2.059 & 12 & 2.085 & 100 \\
\hline 45.12 & 2.0077 & & 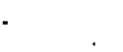 & & & & & & & & & & & \\
\hline 45.42 & 1.9951 & & & & & & & & & & & & & \\
\hline 45.61 & 1.9873 & 15 & & & & & 1.59 & 80 & & & & & & \\
\hline
\end{tabular}


Table A.2. (Continued)

\begin{tabular}{|c|c|c|c|c|c|c|c|c|c|c|c|c|c|c|}
\hline \multirow{2}{*}{$2 \theta$} & \multirow{2}{*}{$\begin{array}{c}d \\
\text { Spaging } \\
(\AA)\end{array}$} & \multirow{2}{*}{$\begin{array}{r}\text { Intensity } \\
\text { (Counts/s) }\end{array}$} & \multicolumn{2}{|c|}{$\mathrm{Na}_{6} \mathrm{Al}_{4} \mathrm{Si}_{4} \mathrm{O}_{17}$} & \multicolumn{2}{|c|}{ LiOH } & \multicolumn{2}{|c|}{$8-\mathrm{Al}_{2} \mathrm{O}_{3}$} & \multicolumn{2}{|c|}{$\mathrm{Al}_{2} \mathrm{SiO}_{5}$} & \multicolumn{2}{|c|}{$\mathrm{SiO}_{2}$} & \multicolumn{2}{|c|}{$\alpha-\mathrm{Al}_{2} \mathrm{O}_{3}$} \\
\hline & & & $d$ & $I / I_{1}$ & $d$ & $I / I_{1}$ & $d$ & $I / I_{1}$ & $d$ & $I / I_{1}$ & $d$ & $I / I_{1}$ & $d$ & $I / I_{1}$ \\
\hline 45.70 & 1.9836 & & & & & & & & 1.98 & 20 & & & & \\
\hline 46.28 & 1.9600 & & & & & & & & 1.96 & 20 & & . & 1.964 & 2 \\
\hline 46.51 & 1.9509 & & & & & & 1.95 & 30 & & & & & & \\
\hline 46.93 & 1.9344 & 5 & & & & & & & & & 1.930 & 2 & & \\
\hline 47.60 & 1.9087 & & & & & & 1.91 & 20 & & & & & & \\
\hline 48.83 & 1.8635 & & & & & & & & 1.868 & 50 & 1.863 & 6 & & \\
\hline 49.15 & 1.8521 & & & & 1.85 & 50 & & & & & & & & \\
\hline 49.45 & 1.8416 & 1.5 & 1.821 & 16 & & & & & 1.829 & 60 & & & & \\
\hline 50.82 & 1.7951 & & & & & & 1.80 & 20 & & & & & & \\
\hline 51.00 & 1.7892 & & & & & & & & & & & & & \\
\hline 51.08 & 1.7862 & 8 & & & 1.78 & 75 & & & & & & & & \\
\hline 52.79 & 1.7326 & 5 & & & & & & & & & & & 1.740 & 45 \\
\hline 52.92 & 1.7287 & & & & & & & & & & & & & \\
\hline 53.50 & 1.7113 & & & & & & & & 1.710 & 8 & & & & \\
\hline 54.17 & 1.6917 & & & & & & & & & & & & & \\
\hline 54.59 & 1.6797 & & & & & & & & & & & & & \\
\hline 54.67 & 1.6774 & & & & & & & & & & & & & \\
\hline 55.58 & 1.6521 & & & & 1.65 & 70 & & & & & 1.651 & 4 & & \\
\hline 56.57 & 1.6255 & & & & 1.64 & 70 & & & & & & & & \\
\hline 56.85 & 1.6182 & & & & & & & & & & 1.619 & 6 & & \\
\hline 57.66 & 1.5973 & 7 & & & & & & & & & & & 1.601 & 80 \\
\hline 57.76 & 1.5948 & & & & & & & & & & & & & \\
\hline 57.92 & 1.5908 & 7 & & & & & & & & & & & & \\
\hline 58.23 & 1.5823 & & & & & & & & & & & & & \\
\hline 59.25 & 1.5582 & & & & & & & & & & & & & \\
\hline 59.74 & 1.5466 & & & & & & & & & & & & 1.546 & 4 \\
\hline 59.90 & 1.5428 & & & & & & 1.54 & 40 & & & 1.542 & 10 & & \\
\hline 60.66 & 1.5253 & & & & & & 1.51 & 30 & & & 1.531 & 2 & 1.514 & 6 \\
\hline 62.43 & 1.4863 & & 1.486 & 30 & 1.49 & 70 & 1.49 & 40 & & & & & & \\
\hline 62.51 & 1.4845 & & & & & & & & & & & & & \\
\hline
\end{tabular}


Table A.2. (Continued)

\begin{tabular}{|c|c|c|c|c|c|c|c|c|c|c|c|c|c|c|}
\hline \multirow{2}{*}{$2 \theta$} & \multirow{2}{*}{$\begin{array}{c}d \\
\text { Spaçing } \\
\text { (A) }\end{array}$} & \multirow{2}{*}{$\begin{array}{l}\text { Intensity } \\
\text { (Courts/s) }\end{array}$} & \multicolumn{2}{|c|}{$\mathrm{Na}_{6} \mathrm{Al}_{4} \mathrm{Si}_{4} \mathrm{O}_{17}$} & \multicolumn{2}{|c|}{$\mathrm{LIOH}$} & \multicolumn{2}{|c|}{$\delta-\mathrm{Al}_{2} \mathrm{O}_{3}$} & \multicolumn{2}{|c|}{$\mathrm{H}_{2} \mathrm{SiO}_{5}$} & \multicolumn{2}{|c|}{$\mathrm{SiO}_{2}$} & \multicolumn{2}{|c|}{$\alpha-\mathrm{Al}_{2} \mathrm{O}_{3}$} \\
\hline & & & $d$ & $I^{\prime} I_{1}$ & $d$ & $I / I_{1}$ & $d$ & $I / I_{1}$ & $d$ & $I / I_{1}$ & $d$ & $I / I_{1}$ & $d$ & $I / I_{1}$ \\
\hline 65.78 & 1.4184 & & & & & & & & & & & & & \\
\hline 65.85 & 1.4171 & & & & & & & & & & & & & \\
\hline 66.04 & 1.4135 & & & & & & & & & & & & & \\
\hline 66.74 & 1.4004 & 6 & 1.404 & 4 & & & 1.40 & 60 & & & & & 1.404 & 30 \\
\hline 67.28 & 1.3904 & & & & & & & & & & & & & \\
\hline 67.45 & 1.3873 & & & & & & & & & & & & & \\
\hline 67.58 & 1.3850 & 13 & & & & & 1.39 & 100 & & & & . & & \\
\hline 67.70 & 1.3828 & & & & 1.38 & 30 & & & & & & & & \\
\hline 68.10 & 1.3757 & & & & & & & & & & & & 1.374 & 50 \\
\hline 68.35 & 1.3712 & & & & & & & & & & & & & \\
\hline 68.63 & 1.3663 & & & & & & & & & & & & & \\
\hline 70.50 & 1.3346 & 2 & & & 1.34 & 30 & & & & & & & 1.337 & 2 \\
\hline 71.69 & 1.3153 & & & & & & & & & & & & & \\
\hline 73.00 & 1.2949 & 11.5 & & & & & & & & & & & & \\
\hline 73.23 & 1.2914 & & & & & & $\cdot$ & & & & & & & \\
\hline 73.32 & 1.2901 & & & & & & 1.29 & 20 & & & & & & \\
\hline 74.07 & 1.2788 & 1.5 & 1.287 & 10 & & & & & & & & & & \\
\hline 74.46 & 1.2731 & 1.5 & & & 1.28 & 50 & & & & & & & 1.276 & 4 \\
\hline 75.25 & 1.2617 & & & & 1.26 & 60 & 1.26 & 10 & & & & & & \\
\hline 75.35 & 1.2603 & & & & & & & & & & & & & \\
\hline 75.74 & 1.2547 & 2 & & & & & & & & & & & & \\
\hline 76.63 & 1.2424 & 1.5 & & & & & & & & & & & 1.239 & 16 \\
\hline 77.18 & 1.2349 & 1 & 1.232 & 4 & & & & & & & & & 1.2343 & 8 \\
\hline 78.32 & 1.2197 & 1 & & & 1.21 & 40 & & & & & & & & \\
\hline 79.63 & 1.2029 & 1.5 & & & & & & & & & & & & \\
\hline 79.99 & 1.1983 & & & & & & & & & & & & & \\
\hline 81.03 & 1.1857 & & & & & & & & & & & & 1.1898 & 8 \\
\hline 81.94 & 1.1748 & & & & & & & & & & & & & \\
\hline 84.35 & 1.1472 & : & 1.152 & 10 & 1.14 & 50 & & & & & & & 1.147 & 6 \\
\hline 87.96 & 1.1092 & $\therefore$ & & & 1.12 & 40 & & & & & & & & \\
\hline
\end{tabular}


Table A.2. (Continued)

\begin{tabular}{|c|c|c|c|c|c|c|c|c|c|c|c|c|c|c|}
\hline \multirow{2}{*}{$2 \theta$} & \multirow{2}{*}{$\begin{array}{c}d \\
\text { Spaçing } \\
(\AA)\end{array}$} & \multirow{2}{*}{$\begin{array}{r}\text { Intensity } \\
\text { (Counts/s) }\end{array}$} & \multicolumn{2}{|c|}{$\mathrm{Ne}_{6} \mathrm{Al}_{4} \mathrm{Si}_{4} \mathrm{O}_{17}$} & \multicolumn{2}{|c|}{$\mathrm{LIOH}$} & \multicolumn{2}{|c|}{$8-\mathrm{Al}_{2} \mathrm{O}_{3}$} & \multicolumn{2}{|c|}{$\mathrm{Al}_{2} \mathrm{SiO}_{5}$} & \multicolumn{2}{|c|}{$\mathrm{S}^{10} \mathrm{O}_{2}$} & \multicolumn{2}{|c|}{$\alpha-\mathrm{Al}_{2} \mathrm{O}_{3}$} \\
\hline & & & $d$ & $I / I_{1}$ & $d$ & $I / I_{1}$ & $d$ & $I / I_{1}$ & $d$ & $I / I_{1}$ & $d$ & $I / I_{1}$ & $d$ & $I / I_{1}$ \\
\hline 88.22 & 1.1066 & & & & & & & & & & & & & \\
\hline 89.12 & 1.0978 & 1 & & & 1.09 & 10 & & & & & & & & \\
\hline 90.16 & 1.0878 & & & & & & & & & & & & & \\
\hline 90.43 & 1.0852 & & & & & & & & & & & & & \\
\hline 90.61 & 1.0836 & & & & & & & & & & & & & \\
\hline 92.13 & 1.0696 & & & & 1.07 & 20 & & & & & & & & \\
\hline 92.71 & 1.0644 & & & & & & & & & & & & & \\
\hline 94.67 & 1.0475 & & & & & & & & & & & & & \\
\hline 95.41 & 1.0413 & 1 & & & 1.04 & 40 & & & & & & & & \\
\hline 95.98 & 1.0366 & 1 & & & & & & & & & & & & \\
\hline 96.46 & 1.0328 & 1 & & & & & & & & & & & & \\
\hline 98.17 & 1.0193 & & & & & & & & & & & & & \\
\hline 98.65 & 1.0156 & & & & & & & & & & & & & \\
\hline 99.35 & 1.0103 & & & & & & & & & & & & & \\
\hline 99.96 & 1.0058 & & & & & & & & & & & & & \\
\hline 100.55 & 1.0015 & & & & & & & & & & & & & \\
\hline 101.16 & 0.9971 & 1 & & & 0.998 & 50 & & & & & & & 0.9976 & 12 \\
\hline 101.48 & 0.9948 & 1 & & & & & & & & & & & & \\
\hline 101.74 & 0.9930 & & & & & & & & . & & & & & \\
\hline 102.74 & 0.9860 & & & & & & & & & & & & & \\
\hline 103.40 & C. 9815 & & & & & & & & & & & & & \\
\hline 103.74 & 0.9792 & & & & & & & & & & & & & \\
\hline 104.36 & 0.9751 & & 0.975 & 6 & & & & & & & & & & \\
\hline 105.43 & 0.9681 & 1 & & & & & & & & & & & & \\
\hline 106.76 & 0.9597 & 1 & & & & & & & & & & & & \\
\hline 107.66 & 0.9542 & & & & & & & & & & & & & \\
\hline 107.74 & 0.9537 & & & & & & & & & & & & & \\
\hline 108.05 & 0.9518 & & & & & & & & & & & & & \\
\hline 109.08 & 0.9456 & & & & & & & & & & & & & \\
\hline
\end{tabular}




\section{THIS PAGE WAS INTENTIONALLY LEFT BLANK}




\section{INTERNAL DISTRIBUTION}

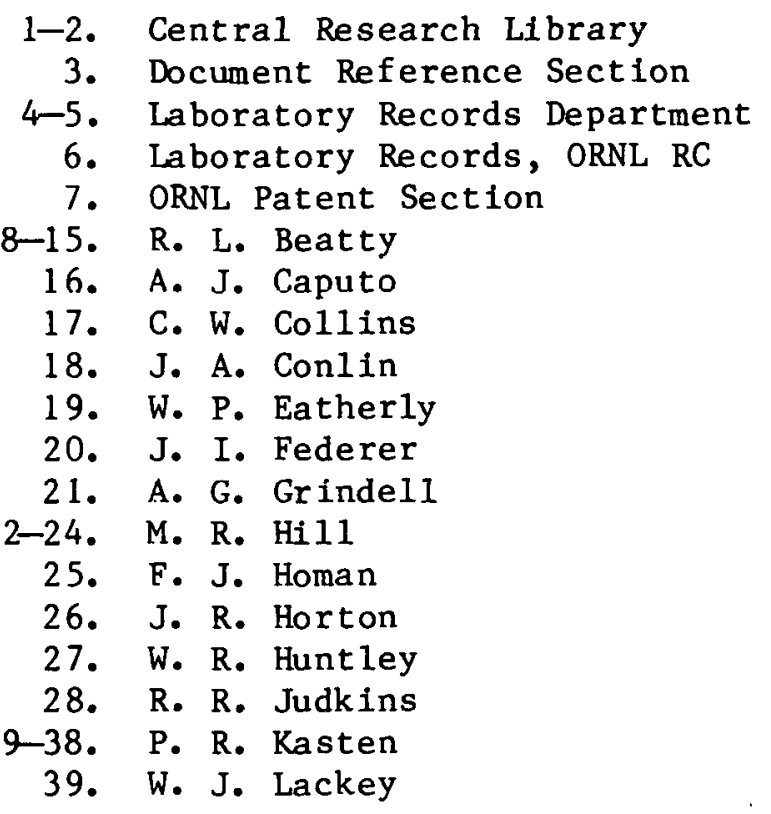

1-2. Central Research Library

40. R. J. Lauf

41. D. L. McE1roy

42. D. J. Naus

43. A. E. Pasto

44-48. P. L. Rittenhouse

49. G, C. Robinson

50. J. P. Sanders

51. A. C. Schaffhauser

52. V. J. Tennery

53. S. M. Tiegs

54. G. C. Wei

55. A. L. Bement, Jr. (Consultant)

56. E. H. Kottcamp, Jr. (Consultant)

57. Alan Lawley (Consultant)

58. T. B. Massalski (Consultant)

59. M. J. Mayfield (Consultant)

60. R. H. Redwine (Consultant)

61. John Stringer (Consultant)

EXTERNAL DISTRIBUTION

62-63. DOE, GAS-COOLED REACTOR PROGRAMS DIVISION, Washington, DC 20545

G. A. Newby

J. E. Fox

64. DUE, OFFICE OF ADVANCED NUCLEAR SYSTEMS AND PROJECTS, Washington, DC 20545

Director

65. SAN-DEVELOPMENT, SAN DIEgo AREA OFFICE, P.0. Box 81325, San Diego, CA 92138

Senior Program Coordinator

66. DOE, SAN FRANCISCO OPERATIONS OFFICE, 1333 Broadway, Wells Fargo Building, Oakland, CA 94612

Manager

67-68. DOE, OAK RIDGE OPERATIONS OFFICE, P.O. Box E, Oak Ridge, TN 37830

office of Assistant Manager for Research and Development

Director, Nuclear Research and Development Division 
69-233. DOE, TECHNICAL INFORMATION CENTER, P.0. BOx 62, Oak Ridge, TN 37830 For distribution as shown in TID- 4500 Distribution Category, UC-77 (Gas-Cooled Reactor Technology) 